\title{
FREE AT LAST! \\ ANTI-SUBORDINATION AND THE THIRTEENTH AMENDMENT
}

\author{
REBECCA E. ZIETLOW*
}

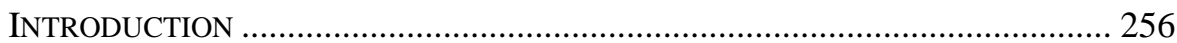

I. AN ANTI-SUBORDINATION THEORY OF EQUALITY ............................ 262

II. THE THIRTEENTH AMENDMENT DEBATES ......................................... 268

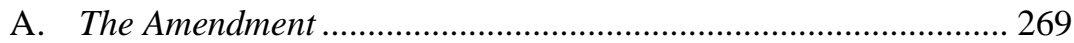

B. The Battle for Approval ............................................................. 271

C. Debates and Meaning ............................................................. 272

D. The Scope of the Enforcement Power and Judicial

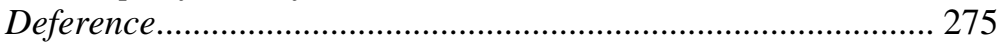

III. ENFORCING THE AMENDMENT - RECONSTRUCTION ........................... 277

A. Civil Rights Legislation ............................................................... 279

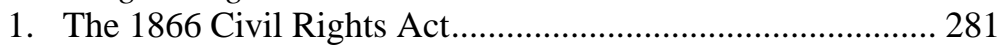

2. The 1871 Enforcement Act ................................................... 284

B. Protecting the Rights of Workers with the Anti-Peonage

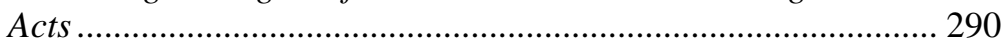

IV. ENFORCING THE AMENDMENT - THE NEW DEAL …............................. 294

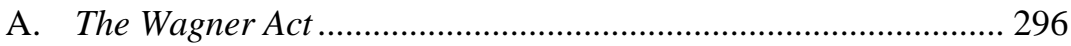

B. The 1948 Anti-Peonage Act ....................................................... 299

V. ENFORCING THE AMENDMENT - THE SECOND RECONSTRUCTION

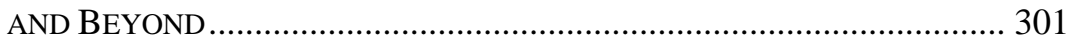

A. 1968 Fair Housing Act ............................................................ 302

B. Trafficking Victims Protection Act of 2000 ................................. 306

CONCLUSION: FREED AT LAST! THE FUTURE OF SECTION 2 ........................... 311

Notwithstanding the powerful symbolism that liberty has in the American psyche, liberty is largely absent from our late twentieth century understanding of civil rights, which instead is based on the Equal Protection Clause and its

\footnotetext{
* Charles W. Fornoff Professor of Law and Values, The University of Toledo College of Law. Thanks to Risa Goluboff, Maria Ontiveros, James Gray Pope, Nicole Porter, and Lee Strang for comments on earlier drafts. I presented versions of this Article at the 2008 Annual Meeting of the Law and Society Association and at the Slavery, Abolition, and Human Rights: Interdisciplinary Perspectives on the Thirteenth Amendment conference at the University of Chicago in April 2009. Thanks to all who heard and commented on my talks. Thanks to the University of Toledo College of Law for providing funding for my research. Finally, special thanks to my research assistants, David Cowen and Brianna White.
} 
promise of formal equality. People of color and women of every race have made significant advances under the equal protection model of equality, but they continue to lag behind whites and men under virtually every economic index. This Article argues for an alternative model of equality, an antisubordination model, which allows decision-makers to focus on and remedy the material conditions that contribute to inequality in our society. This model can be found in another Reconstruction Amendment, the Thirteenth Amendment, which empowers Congress to remedy racial and economic subordination in order to further the belonging of outsiders in our society. This Article considers the abolitionist roots of the Thirteenth Amendment to aid in an understanding of its potential, and analyzes the congressional debates enacting and enforcing the Amendment. When enforcing the Thirteenth Amendment, Congress has adopted an anti-subordination approach to equality, remedying both race discrimination and the economic subordination of workers. The debates and the legislation itself create a precedent for a twenty-first century Congress to reshape the meaning of "equality" and "liberty" and enact more measures to effectively address the interconnected subordination of people of color, women, and workers of all races.

\section{INTRODUCTION}

For many people, the highlight of the inauguration of the first black President of the United States was Aretha Franklin's rendition of the song, My Country Tis of Thee. ${ }^{1}$ Franklin's voice echoed that of Marion Anderson, who sang the same song on the steps of the Lincoln Memorial in 1939 at the invitation of First Lady Eleanor Roosevelt, after Anderson was denied the opportunity to sing at Constitution Hall because of her race. ${ }^{2}$ The refrain of that song also punctuated Dr. Martin Luther King, Jr.'s I Have a Dream speech in the summer of 1963, as Dr. King called for Congress to enact civil rights legislation. ${ }^{3}$ As the end of Dr. King's speech, "Free at last! Free at last! Thank God almighty, we are free at last!"4 reflects, the promise of liberty has always been a powerful one in our country, not only for African Americans, but for all Americans. Liberty is also essential to an anti-subordination theory of equality, one that takes into account the material circumstances an individual needs to effectively belong and participate in our society. Section 2 of the Thirteenth Amendment ${ }^{5}$ is a potent source of those rights.

\footnotetext{
${ }^{1}$ See Guy Adams, President's Walkabout Warms the Freezing Masses, THE INDEPENDENT, Jan. 21, 2009, at 6.

2 See Allan KeILER, Marian Anderson: A Singer's Journey 181-217 (2000).

3 Taylor Branch, Parting the Waters: America in the King Years 1954-63, at 882 (1988).

${ }^{4}$ Martin Luther King, Jr., I Have a Dream (Apr. 3, 1968), in ThE Words OF MARTIN LUTHER King, JR. 98 (Coretta Scott King ed., 1983).

${ }^{5}$ U.S. CONST. amend. XIII, $\S 2$.
} 
Notwithstanding the songs and the rhetoric, the promise of liberty has largely been absent from our civil rights tradition. Since the 1950 s, our civil rights law has been based not on the Thirteenth Amendment's promise of liberty and equality, but primarily on the Equal Protection Clause of the Fourteenth Amendment. ${ }^{6}$ In the late twentieth century, the equal protectionbased model of civil rights improved the lives of racial minorities and women. ${ }^{7}$ Nevertheless, courts and legislatures enforcing that model have been unable to uproot the deeply entrenched economic inequality that plagues American society because of the model's failure to address the intersection of race and class. ${ }^{8}$

What would equality rights look like if they also encompassed the promise of liberty? One need go back only to the days of Marion Anderson's concert to discover an alternative civil rights tradition, based in the promise of liberty and equality that is embodied in the Thirteenth Amendment. ${ }^{9}$ The Thirteenth Amendment, which states affirmatively, "neither slavery nor involuntary servitude ... shall exist," 10 does far more than simply end chattel slavery in the United States. It is a source of "personal security, labor rights, and rights to minimal economic security"11 because its Framers ${ }^{12}$ intended it to empower

${ }^{6}$ Risa L. Goluboff, The Lost Promise of Civil Rights 4 (2007). Liberty has been defined largely by an absence of government interference rather than the right to government intervention to improve the lives of its citizens. Compare Roe v. Wade, 410 U.S. 113, 152-56, 164-65 (1973) (finding a fundamental right for a woman to choose to have an abortion), with Maher v. Roe, 432 U.S. 464, 473-74, 480 (1977) (finding no constitutional right to government funding of abortions).

7 The courts relied on this model to strike down race-based segregation and laws based on outdated gender stereotypes. See, e.g., United States v. Virginia, 518 U.S. 515, 557 (1996) (finding that the exclusion of women from Virginia Military Institute violated the Equal Protection Clause); Frontiero v. Richardson, 411 U.S. 677, 690-91 (1973) (striking down a law varying military service-dependent benefits based on gender); Loving v. Virginia, 388 U.S. 1, 12 (1967) (striking down laws forbidding interracial marriage); Brown v. Bd. of Educ., 347 U.S. 483, 494 (1954) (holding that racially segregated public schools violate the Equal Protection Clause of the Fourteenth Amendment). Congress also relied on this model in passing the Civil Rights Act of 1964, Pub. L. No. 88-352, 78 Stat. 241, 241-68 (codified as amended at 42 U.S.C. $\S \S 2000 d-2000$ e (2006)) (prohibiting race and gender discrimination in employment, and race discrimination by programs receiving federal funds).

${ }^{8}$ See Rebecca E. Zietlow, Belonging and Empowerment: A New "Civil Rights" Paradigm Based on Lessons of the Past, 25 Const. Comment. 353, 356-61 (2008) (reviewing GolubOFF, supra note 6).

9 See Goluboff, supra note 6, at 16-50.

${ }^{10}$ U.S. CONST. amend. XIII, $\S 1$.

11 GolubofF, supra note 6 , at 11.

12 I use the term "Framers" rather than "drafters" because I believe that the Reconstruction Era was as significant to our constitutional development as the framing of the original Constitution. The members of Congress responsible for the Reconstruction Amendments enacted such momentous change to our constitutional structure that the 
members of Congress to address both racial and economic injustice. ${ }^{13}$ Section 2 of the Thirteenth Amendment authorizes Congress to enforce that promise and create rights of belonging - rights that promote an inclusive vision of who belongs to the national community of the United States and facilitate equal membership in that community. ${ }^{14}$ This is necessary because both racial and economic barriers limit the ability of individuals to fully belong to American society. ${ }^{15}$ When Congress acts to enforce the Thirteenth Amendment, Congress relies on this alternative "anti-subordination" model of rights of belonging.

The United States Supreme Court has rejected the position that economic rights are fundamental rights. ${ }^{16}$ Nevertheless, the Framers of the Thirteenth Amendment did not make such a distinction. They considered some economic rights to be human rights, starting with the right to work for wages without coercion to do so. ${ }^{17}$ They also believed that the right to engage in the economy was a fundamental human right. ${ }^{18}$ Most importantly, they gave future Congresses the authority to determine what other economic rights should be established and protected by the federal government. ${ }^{19}$ Since then, members of Congress enforcing the Thirteenth Amendment have relied on an anti-subordination model of equality, based not solely on equal treatment, but instead recognizing that both racial equality and economic rights are necessary

Reconstruction Era is sometimes referred to as the "Second Founding." See, e.g., Barry Friedman, Reconstructing Reconstruction: Some Problems for Originalists (and Everyone Else, Too), 11 U. PA. J. Const. L. 1201, 1205 (2009).

13 See infra Part II.C.

14 See U.S. ConST. amend. XIII, § 2 ("Congress shall have power to enforce this article by appropriate legislation.").

${ }^{15}$ For a detailed discussion of "rights of belonging," see REBECCA E. ZIETLOw, Enforcing Equality: Congress, the Constitution, AND the Protection of Individual Rights 6-8 (2006) [hereinafter Zietlow, ENForCing EQUALITY].

${ }^{16}$ See, e.g., San Antonio Indep. Sch. Dist. v. Rodriguez, 411 U.S. 1, 29-39 (1973) (declining to find a fundamental right to education in rejecting a challenge to property taxbased funding of public schools); Dandridge v. Williams, 397 U.S. 471, 484-85 (1970) (declining to find a substantive right to welfare benefits and applying rational basis review to restrictions on those benefits). This distinction is absent from the Universal Declaration of Human Rights and other international norms, under which economic rights, including the right to social security, the right to work, the right to "just and favourable remuneration" and the right to form and to join trade unions are considered to be fundamental human rights. See Universal Declaration of Human Rights, G.A. Res. 217A, at 75, U.N. GAOR, 3d Sess., 183d plen. mtg., U.N. Doc A/810 (Dec. 10, 1948).

17 See U.S. Const. amend. XIII, § 1.

18 This vision is most clearly embodied in the 1866 Civil Rights Act, which protects the right of all people to engage in the economy on the same basis "as white citizens." Civil Rights Act of 1866, ch. 31, 1, 14 Stat. 27, 27 (codified as amended at 42 U.S.C. § 1981(a) (2006)).

${ }^{19}$ U.S. CONST. amend. XIII, $§ 2$. 
for true equality. ${ }^{20}$ Section 2 of the Thirteenth Amendment gives Congress the authority to go beyond formal equality and remedy the socioeconomic disparities associated with race and gender that plagues our nation.

To illustrate the anti-subordination theory of equality, this Article analyzes the congressional debates over the Thirteenth Amendment and legislation enforcing it. This Article focuses primarily on Congress's interpretation of the Amendment's meaning, rather than the Court's interpretations. The Court has largely deferred to congressional enforcement of the Thirteenth Amendment, ${ }^{21}$ and Congress's actions in this arena are excellent examples of constitutional interpretation outside of the courts - what Professor Larry Kramer calls "popular constitutionalism." 22 Advocates of popular constitutionalism question the primacy of judicial review over the political branches' constitutional interpretation, ${ }^{23}$ while its critics maintain that judicial review is necessary for stable and principled constitutional interpretation. ${ }^{24}$ This Article maintains that members of Congress, like members of the federal courts, have an obligation to interpret the constitutional provisions they enforce.

When members of Congress debate and enact legislation, they create a record comparable to that of judges writing opinions. ${ }^{25}$ Like judicial opinions, the records of the debates and the legislation itself establish precedent upon which future Congresses can rely. Although the precedent is not binding like judicial precedents, it is helpful for current and future members of Congress who seek to determine the meaning of the Thirteenth Amendment's promise of freedom and equality. Of course, considerations other than constitutional principles may motivate members of Congress when they participate in these debates. Nevertheless, when they act to define and protect rights of belonging, members of Congress express not only a political vision, but also a vision of

20 See infra Parts III-V.

21 See infra notes 174-82 and accompanying text.

22 See Larry D. Kramer, The People Themselves: Popular Constitutionalism and JUdiCIAL REVIEW 8 (2004) (defining "popular constitutionalism" as a phenomenon occurring when "final interpretative authority" rests with the "people themselves" rather than the courts).

${ }^{23}$ See, e.g., id. at 58-59; Robert C. Post \& Reva B. Siegel, Legislative Constitutionalism and Section Five Power: Policentric Interpretation of the Family and Medical Leave Act, 112 YALE L.J. 1943, 1946-47 (2003).

${ }^{24}$ See, e.g., Larry Alexander \& Frederick Schauer, Defending Judicial Supremacy: A Reply, 17 Const. Comment. 455, 455-57 (2000); Erwin Chemerinsky, In Defense of Judicial Review: A Reply to Professor Kramer, 92 CAL. L. Rev. 1013, 1014 (2004).

${ }^{25}$ For a good description of this process, see Keith E. Whittington, Constitutional Construction: Divided Powers and Constitutional Meaning 1, $207-28$ (1999). Reasonable minds may differ over the authoritativeness of the congressional record as a document interpreting the Constitution. This Article assumes that the record is authoritative, as a source of constitutional interpretation that is different from that of the courts, but nevertheless equally valid. See ZiETLOW, ENFORCING EQUALiTY, supra note 15, at $9-10$. 
the meaning of individual rights within our constitutional structure. Congressional debates over legislation enforcing the Thirteenth Amendment provide an excellent example of this phenomenon.

The Supreme Court recently enhanced the importance of Section 2 by deferring to the provision even as it restricted Congress's authority to enact civil rights legislation pursuant to the Commerce Clause and the Fourteenth Amendment. ${ }^{26}$ At the same time, a number of scholars have rediscovered the Thirteenth Amendment, suggesting that it might be a source of power to remedy injustice ranging from racial profiling to the mail order bride business. ${ }^{27}$ Members of Congress also seem to be rediscovering Section 2, after years of neglect. ${ }^{28}$ These developments highlight the need to reconsider the scope and significance of the Section 2 power. Yet until now, no scholar has comprehensively analyzed Congress's use of Section 2. Scholars have predominantly viewed the Thirteenth Amendment as a source of antidiscrimination law that differs from the Fourteenth Amendment not in

${ }^{26}$ See City of Boerne v. Flores, 521 U.S. 507, 520 (1997) (establishing a "congruence and proportionality" test for courts to evaluate the constitutionality of legislation enforcing the Fourteenth Amendment); see also Bd. of Trs. of the Univ. of Ala. v. Garrett, 531 U.S. 356, 372 (2001) (applying the test to strike down the provision of the Americans with Disabilities Act authorizing private enforcement of the Act against state employers); United States v. Morrison, 529 U.S. 598, 607-27 (2000) (striking down civil rights provision of Violence Against Women Act as invalid use of Commerce Clause and Fourteenth Amendment enforcement power); Kimel v. Fla. Bd. of Regents, 528 U.S. 62, 82-83 (2000) (applying the test to strike down the provision of the Age Discrimination in Employment Act authorizing private enforcement of the Act against state employers); United States v. Lopez, 514 U.S. 549, 559 (1995) (applying heightened scrutiny to Commerce Clause-based legislation).

27 See, e.g., William M. Carter, Jr., Race, Rights, and the Thirteenth Amendment: Defining the Badges and Incidents of Slavery, 40 U.C. DAVIS L. REV. 1311, 1313 (2007); Suzanne H. Jackson, Marriages of Convenience: International Marriage Brokers, "MailOrder Brides," and Domestic Servitude, 38 U. ToL. L. REv. 895, 915-19 (2007); Darrell A. Miller, White Cartels, the Civil Rights Act of 1866, and the History of Jones v. Alfred H. Mayer Co., 77 Fordham L. Rev. 999, 1003-04 (2008); Maria L. Ontiveros, Noncitizen Immigrant Labor and the Thirteenth Amendment: Challenging Guest Worker Programs, 38 U. Tol. L. Rev. 923, 923-24 (2007); Alexander Tsesis, A Civil Rights Approach: Achieving Revolutionary Abolitionism Through the Thirteenth Amendment, 39 U.C. DAVIS L. REV. 1773, 1776-77 (2006).

${ }^{28}$ In 2000, Congress relied on Section 2 to enact the Trafficking Victims Protection Act of 2000, Pub. L. No. 106-386, 114 Stat. 1464, 1466-91 (codified as amended at 22 U.S.C. $\S \S 7101-7112$ (2006)). See Trafficking Victims Protection Act of 2000, H.R. 3244, 106th Cong. $\$ 102$ (b)(22) (referencing the Thirteenth Amendment). Congress recently enacted the Local Law Enforcement Hate Crimes Prevention Act of 2009 as a rider to the National Defense Authorization Act for Fiscal Year 2010, H.R. 2647, 111th Cong. §§ 4701-4713 (2009), which is partly based on its Section 2 power. Id. § 4702(7)-(8). 
meaning, but in its applicability to private parties. ${ }^{29}$ This view of the Thirteenth Amendment does not do justice to its potential as a potent source of economic and labor rights based on an alternative anti-subordination model of equality. ${ }^{30}$

It is important to note that the Section 2 power is not unlimited. Section 2 authorizes Congress to end slavery, involuntary servitude, and the badges or incidents of slavery. ${ }^{31}$ The historic link between slavery and race discrimination indicates that this authority extends to enacting civil rights legislation. ${ }^{32}$ Since slavery and involuntary servitude are employment practices, however brutal and inhumane, Section 2 also authorizes Congress to remedy exploitative conditions in the workplace. ${ }^{33}$ Nonetheless, Section 2 is not a font of general civil or criminal law. Instead, Section 2 fits well within the system of federalism established by the Reconstruction Congress that gives the federal government primary responsibility over rights of belonging. ${ }^{34}$ Most importantly, Section 2 enables the twenty-first century Congress to reconsider the meaning of belonging, equality, and liberty, and to synthesize these concepts into a meaningful policy of anti-subordination.

Part I of this Article discusses two models of equality: formal equality and anti-subordination. While the courts have limited the Equal Protection Clause to the formal model, the Thirteenth Amendment provides a new, more robust model of equality rooted in anti-subordination. This new model goes beyond requiring mere equal treatment and considers the practical impact of policies on those who have been historically subordinated in our society. Part II analyzes the debates over the Thirteenth Amendment as abolitionist members of Congress enshrined their vision of liberty and equality into the Constitution. Part III is an in-depth analysis of the Reconstruction Era statutes based in Section 2, analyzing both the historical context and the debates over those statutes to consider their meaning as historical precedents. The Reconstruction Era statutes reflect an anti-subordination theory of equality based in economic rights as well as racial equality. Members of the Reconstruction Congress

${ }^{29}$ Recent works considering the Thirteenth Amendment as a source of antidiscrimination legislation include Carter, supra note 27, at 1313; Miller, supra note 27, at 1003-04; Tsesis, supra note 27, at 1776-77; Alexander Tsesis, Furthering American Freedom: Civil Rights and the Thirteenth Amendment, 45 B.C. L. REv. 307, 308 (2004).

30 See Ontiveros, supra note 27, at 923.

31 Jones v. Alfred H. Mayer, Co., 392 U.S. 409, 440 (1968); Clyatt v. United States, 197 U.S. 207, 218 (1905).

32 See infra notes 191-99 and accompanying text.

33 See infra notes 284-97 and accompanying text.

34 See Denise C. Morgan \& Rebecca E. Zietlow, The New Parity Debate: Congress and Rights of Belonging, 73 U. CIN. L. REV. 1347, 1399 (2005) (describing "rights of belonging" as "those that promote an inclusive vision of who belongs to the United States' national community and facilitate equal membership in that community" such as voting and property rights as well as rights to a living wage, an adequate education, and equal access to public accommodation). 
understood that slavery was not just a system of racial subordination, but also an exploitative system of labor. They created a paradigm for an antisubordination approach to the intersection of race and class that characterizes inequality in American society.

Part IV describes the model of individual rights that the political branches adopted during the New Deal Era. That model started not with racial equality, but with economic rights. Members of Congress evoked the Thirteenth Amendment when creating a statutory right to organize and bargain collectively with the Wagner Act. ${ }^{35}$ While members of Congress omitted racial equality from their New Deal vision, the Justice Department, under President Roosevelt, worked to expand rights for racial minorities, and convinced Congress to modernize and expand the meaning of the AntiPeonage Act with an amendment. ${ }^{36}$ Part V considers the New Reconstruction of the 1960s, an era in which the rights paradigm shifted to an equal protection model with less emphasis on economic rights. Nevertheless, even during that era, Congress used its Section 2 power to legislate against economic barriers and hate crimes confronting racial minorities in the 1968 Fair Housing Act. ${ }^{37}$ In 2000, members of Congress also adopted an anti-subordination theory of equality when they relied on Section 2 to legislate against the international trafficking of sex and other workers with the Trafficking Victims Protection Act of 2000 ("TVPA"). 38 The TVPA uses a comprehensive approach to address the economic, racial, and gender based causes of inequality in the international labor market. This Article concludes by considering the rich potential of Section 2 as a source of a new vision of equality in the twenty-first century.

\section{AN ANTI-SUBORDINATION THEORY OF EQUALITY}

Anti-subordinating rights of belonging have their roots in the post-Civil War Era because Republican members of the Reconstruction Congress wanted to include newly freed slaves in the national polity. The Supreme Court's 1856 ruling in Scott v. Sandford ${ }^{39}$ was profoundly exclusionary, as Justice Taney declared that people of African descent could not be United States citizens. ${ }^{40}$ After the Civil War, members of the Reconstruction Congress overturned Dred Scott, declared freed slaves to be citizens, and gave themselves power to define

\footnotetext{
35 See National Labor Relations Act, ch. 372, 49 Stat. 449, 449 (1935); infra Part IV.A.

36 See Anti-Peonage Act, ch. 187, 14 Stat. 546, 546 (codified as amended at 18 U.S.C. $\S$ 1581 and 42 U.S.C. $\$ 1994$ (2006)).

37 See Fair Housing Act of 1968, Pub. L. No. 90-284, 82 Stat. 81 (codified as amended at 42 U.S.C. $\S \S 3601-3631$ ).

38 See Trafficking Victims Protection Act of 2000, Pub. L. No. 106-386, 114 Stat. 1464, 1490 (codified as amended at 22 U.S.C. $\$ \$ 7101-7112$ (2006)).

39 Scott v. Sandford (Dred Scott), 60 U.S. (19 How.) 393 (1856).

40 See id. at 407-18.
} 
and protect fundamental human rights. ${ }^{41}$ When Congress enacted the Thirteenth Amendment, it abolished slavery and gave itself the power to remedy slavery's legacy. ${ }^{42}$ Since slavery was an exploitative economic relationship based on the ideology of racial supremacy, members of the Reconstruction Congress relied on the Thirteenth Amendment to address the link between economic exploitation and race, and to establish the right to work free of economic exploitation.

During the twentieth century, the Jim Crow system enabled exploitation of black workers in the South. ${ }^{43}$ Black agricultural workers were treated only slightly better than slaves, denied access to basic government services, and subjected to brutal violence if they attempted to assert what rights they had under the law. ${ }^{44}$ In the North, black workers were paid less and limited to less desirable jobs than white workers due to a slightly less virulent form of racism and segregation. ${ }^{45}$ Racism against blacks also contributed to exploitation of white workers by creating a downward pressure on the labor market. ${ }^{46}$ Thus, even after slavery ended, blacks experienced the same pattern of racial and economic subordination that had characterized the institution of slavery.

In the 1954 case of Brown v. Board of Education, ${ }^{47}$ the Court held that state mandated segregation of public schools violated the Equal Protection Clause of the Fourteenth Amendment. ${ }^{48}$ Largely due to the plaintiffs' dramatic success in Brown, the Equal Protection Clause has been the focus of civil rights litigation ever since. ${ }^{49}$ Advocates for racial equality convinced the courts to strike down legislation that treated people unequally on the basis of race. ${ }^{50}$ Advocates for gender equality relied on the Brown paradigm to convince courts to strike down legislation that treated women unequally based on outdated gender stereotypes. ${ }^{51}$ At the same time, Congress enacted legislation enforcing the right to equal protection of the laws for racial minorities, women, the disabled, and the elderly. ${ }^{52}$ The Equal Protection Clause conveys a potent

\footnotetext{
41 See U.S. CONST. amend. XIV.

42 See U.S. CONST. amend. XIII.

43 GolubofF, supra note 6, at 6-7.

${ }^{44} \mathrm{Id}$.

${ }^{45} I d$. at 81-82.

46 See Robert Samuel Smith, Race, Labor \& Civil Rights 11 (2008).

47347 U.S. 483 (1954).

${ }^{48} I d$. at 495.

49 See Goluboff, supra note 6, at 240.

50 See, e.g., Loving v. Virginia, 388 U.S. 1, 12 (1967).

51 See, e.g., United States v. Virginia, 518 U.S. 515, 545-46 (1996); Frontiero v. Richardson, 411 U.S. 677, 690-91 (1973).

52 See, e.g., Education for All Handicapped Children Act of 1975, Pub. L. No. 94-142, 89 Stat. 773 (codified as amended at 20 U.S.C. $\$ \S 1400-1482$ (2006)) (requiring public schools to give equal opportunities to disabled children); Education Amendments of 1972, Pub. L. No. 92-318, 86 Stat. 235 (codified as amended at 20 U.S.C. $\S \S 1681-1688$ ) (prohibiting
} 
message of equality and dignity for all people in our country. Moreover, the rights to be free of race based segregation, gender discrimination, and other discrimination based on immutable characteristics, are fundamental human rights. Thus, much has been gained from court and legislative enforcement of the equal protection model. ${ }^{53}$

Nevertheless, advocates for rights of belonging who wished to enforce these rights through the Equal Protection Clause ran into several significant roadblocks. The first roadblock was the Civil Rights Cases, ${ }^{54}$ an 1883 precedent in which the Court held that the Fourteenth Amendment only applies to state action and does not extend to private discrimination. ${ }^{55}$ Second, the Court held that plaintiffs in equal protection cases must prove that the state intentionally discriminated against them, because state practices that have only a discriminatory impact do not violate the Clause. ${ }^{56}$ Often, government policies that are based on economics have a disparate impact on racial minorities. For example, blacks may find it harder to get a job that requires a standardized test ${ }^{57}$ because they are far more likely to attend substandard, inner-city public schools. ${ }^{58}$ Similarly, zoning laws that require single-family

discrimination on the basis of gender by educational entities receiving federal funds); Elementary and Secondary Education Act of 1965, Pub. L. No. 89-10, 79 Stat. 27 (codified as amended in scattered sections of 20 U.S.C.) (providing support to meet the educational needs of children with disabilities); Rehabilitation Act of 1973, Pub. L. No. 93-112, 87 Stat. 355 (codified as amended at 29 U.S.C. $\$$ 701-796 (2006)) (prohibiting discrimination on the basis of disability by recipients of federal funds); Civil Rights Act of 1964, Pub. L. No. 88-352, 78 Stat. 241 (codified as amended at 42 U.S.C. $\S \S 2000$ d-2000e (2006)) (prohibiting discrimination in employment on the basis of race, color, religion, sex, or national origin and prohibiting discrimination on the basis of race, color, or national origin by recipients of federal funds); Age Discrimination Act of 1975, Pub. L. No. 94-135, 89 Stat. 728 (codified as amended at 42 U.S.C. §§ 6101-6107 (2006)) (prohibiting discrimination in employment on the basis of age); Americans with Disabilities Act of 1990, Pub. L. No. 101-336, 104 Stat. 330 (codified as amended in scattered sections of 42 U.S.C.) (prohibiting discrimination in employment and places of public accommodation on the basis of disability).

53 Due to the state action limitation on Congress's power to enforce the Equal Protection Clause, members of Congress based many of these measures on the Commerce Power instead, even as they evoked images of equal protection. Rebecca E. Zietlow, To Secure These Rights: Congress, Courts and the 1964 Civil Rights Act, 57 RutGERs L. REV. 945, 977-79 (2005) [hereinafter Zietlow, To Secure].

54109 U.S. 3 (1883).

55 Id. at 11 . The Court recently reaffirmed the holding that Congress cannot use its power to enforce the Fourteenth Amendment to address private action in United States $v$. Morrison, 529 U.S. 598, 621 (2000).

56 Washington v. Davis, 426 U.S. 229, 239-45 (1976).

57 See id. at 232-33.

${ }^{58}$ For example, in 1998, the National Center for Educational Statistics reported that while eighty-one percent of white eighth graders had basic reading skills, only fifty percent of black students had achieved that level. The Mid-AtLantic Equity Consortium, 
housing may have the effect of excluding blacks from neighborhoods because they are less likely to be able to afford single-family homes. ${ }^{59}$ Currently, however, there are few, if any, remedies for people who suffer from such policies. ${ }^{60}$ Finally, the Court adopted a symmetrical formal equality approach to measures adopted to alleviate societal discrimination against women and racial minorities, applying the same heightened level of scrutiny to "benign" classifications and striking down affirmative action measures. ${ }^{61}$

More than fifty years after Brown, and forty years after the 1964 Civil Rights Act, African Americans still lag behind whites, and women behind men, in virtually every indicator of economic success. ${ }^{62}$ Neither the promise of racial equality in the Equal Protection Clause nor the protections of workers in our statutory law have succeeded in closing this gap. Dissatisfied by the

NATIONAL EQUity STATISTICS \& OTHER EQUiTy InDiCATORS, http://www.maec.org/ natstats.html\#naepread8 (last visited Nov. 21, 2009). The Civil Rights Project at Harvard University found a growing number of racially segregated schools where "enormous poverty, limited resources, and social and health problems of many types are concentrated." Erica Frankenberg, Chungmei Lee \& Gary Orfield, Civil Rights Project, Harvard Univ., A Multiracial Society with Segregated Schools: Are We Losing the Dream? (2003), available at http://www.civilrightsproject.ucla.edu/research/reseg03/ AreWeLosingtheDream.pdf (using data from the U.S. Department of Education's National Center for Education Statistics).

59 See Village of Arlington Heights v. Metro. Hous. Dev. Corp., 429 U.S. 252, 264-71 (1977) (denying relief to petitioners who alleged that single-family home zoning ordinance had a disparate impact on low and moderate income individuals); Warth v. Seldin, 442 U.S. 490, 514-17 (1975) (affirming procedural dismissal of complaint alleging that city ordinance requiring single-family homes had a disparate impact on low and moderate income minority individuals).

${ }^{60}$ For example, federal regulations for federally subsidized housing under the Section 8 program prohibit discrimination based on "race, color, religion, sex, national origin, age, familial status or disability" but not level of income. 24 C.F.R. § 982.304 (2009).

${ }^{61}$ E.g., Parents Involved in Cmty. Sch. v. Seattle Sch. Dist. No. 1, 551 U.S. 702, 725-35, 745-48 (2007) (striking down local measures designed to reduce racial disparities in public schools as discriminating on the basis of race); Gratz v. Bollinger, 539 U.S. 244, 276 (2003) (striking down University of Michigan undergraduate admissions affirmative action program as discriminating on the basis of race); Adarand Constructors, Inc. v. Pena, 515 U.S. 200, 227 (1995) (holding that all race based classifications are subject to strict scrutiny).

${ }^{62}$ For example, in 2004 , black households had a median income of $\$ 30,134$, while overall median income was $\$ 44,389$. Press Release, U.S. Census Bureau News, Income Stable, Poverty Rate Increases, Percentage of Americans Without Health Insurance Unchanged (Aug. 30, 2005), http://www.census.gov/Press-Release/www/releases/archives/ income_wealth/005647.html. The U.S. Department of Labor, Bureau of Labor Statistics, reports that in 2008, women in full-time employment earned about eighty percent of the wages and salary that men did. U.S. DeP'T OF LABOR, Bureau of Labor Statistics, Highlights OF WOMEN's EARNINGS IN 2008, at 1 (2009), available at http://www.bls.gov/cps/cpswom2008.pdf. 
inability of the formal equality paradigm to address the roots of inequality, some scholars have called for courts to adopt an "anti-subordination" paradigm, outlawing race or gender based practices that further the subordination of those who have suffered a history of discrimination. ${ }^{63}$ An anti-subordination approach to equal protection would enable lawmakers to go beyond formalistic doctrine and remedy the root causes of inequality. Yet the anti-subordination approach fits awkwardly within the Equal Protection Clause, which on its face seems to require no more than equal treatment and neutrality. ${ }^{64}$ Moreover, it is not at all clear that courts are well qualified to determine which practices are "subordinating" and which are not. Indeed, the Supreme Court has gone the opposite direction in its interpretation of the Equal Protection Clause, adopting a color-blind model and striking down affirmative action programs designed along the anti-subordination model. ${ }^{65}$ In addition, the Court has made it clear that Congress lacks the power to adopt antisubordination policies that are inconsistent with its interpretation of the Equal Protection Clause. ${ }^{66}$

By contrast to the Equal Protection Clause, the Thirteenth Amendment is facially based on an anti-subordination model because its promise that "neither slavery nor involuntary servitude ... shall exist" 67 is a positive guarantee against both race discrimination and the exploitation of workers. ${ }^{68}$ The Thirteenth Amendment also guarantees freedom from the "badges and incidents of slavery," 69 including racial violence, lack of physical mobility, and the involuntary separation of family members. ${ }^{70}$ This ban on slavery and involuntary servitude clearly is not neutral because it gives workers rights

${ }^{63}$ See, e.g., Ruth Colker, Anti-Subordination Above All: Sex, Race, and Equal Protection, 61 N.Y.U. L. REv. 1003, 1007-11 (1986); Victor C. Romero, Are Filipinas Asians or Latinas?: Reclaiming the Anti-Subordination Objective of Equal Protection After Grutter and Gratz, 7 U. PA. J. Const. L. 765, 780 (2005).

64 See U.S. CONST. amend. XIV.

65 See, e.g., Parents Involved, 551 U.S. at 725-35, 745-48; Gratz, 539 U.S. at 276; Adarand, 515 U.S. at 227.

66 See Zietlow, EnForcing EQuality, supra note 15, at 10.

${ }^{67}$ U.S. CONST. amend. XIII, § 1.

68 The Court has recognized this fact since the Civil Rights Cases. See The Civil Rights Cases, 109 U.S. 3, 20 (1883) ("[T]he Thirteenth Amendment may be regarded as nullifying all State laws which establish or uphold slavery. But it has a reflex character also, establishing and decreeing universal civil and political freedom throughout the United States; and it is assumed, that the power vested in Congress to enforce the article by appropriate legislation, clothes Congress with power to pass all laws necessary and proper for abolishing all badges and incidents of slavery in the United States . . . "); infra Part II.C.

69 The Civil Rights Cases, 109 U.S. at 20.

70 See Robert K. Carr, Federal Protection of Civil Rights: Quest for a Sword 151 (1947) (describing the strategy of the Civil Rights Section of the Department of Justice in combating racial violence, worker exploitation, and the lack of mobility). 
against their masters. It aims to destroy a hierarchical system and to empower those that suffered under that system.

Prior to the Civil War, anti-slavery constitutionalists stressed the fundamental human rights of slaves to argue in favor of abolishing slavery and legislating to protect those rights. ${ }^{71}$ They recognized that under the system of slavery, combined racism and economic subordination facilitated the exploitation of all workers in our country. ${ }^{72}$ Slavery is the most obvious and extreme example of this phenomenon. ${ }^{73}$ Slaveholders justified their treatment of human beings as property by arguing that the slaves belonged to an inferior race. ${ }^{74}$ The African origins of slaves made them easier to identify and therefore facilitated the capture of runaway slaves. ${ }^{75}$ Perhaps most importantly, slave owners relied upon racism to differentiate slaves from poor white workers and justify their poor treatment of the white workers. ${ }^{76}$

In 1856, James Ashley, who was to become the original author and chief proponent of the Thirteenth Amendment in the House of Representatives, presciently pointed out the relationship between race discrimination and the economic subordination of blacks. ${ }^{77} \mathrm{He}$ observed, "Wherever the negro is free and educated and owns property, you will find him respected and treated with consideration." 78 Ashley thus acknowledged the interconnection between race and class subordination that underlay slavery and harmed all workers by disempowering them in their relationships with employers. ${ }^{79}$ After the Civil War, Ashley and his colleagues in the Reconstruction Congress worked to remedy the racial and economic degradation experienced by former slaves by enacting laws to create both economic rights and freedom from race discrimination. ${ }^{80}$

71 See Zietlow, Enforcing Equality, supra note 15, at 19-37.

72 See Eric Foner, Free Soil, Free Labor, Free Men: The Ideology of the RePUBlican PARTy BeFORE THE CIVIL WAR 11 (1995).

73 See id. at 45.

74 See, e.g., George Fitzhugh, Sociology for the South; OR, The Failure of Free SOCIETY 177-82 (Richmond, Va., A. Morris 1854) (writing that "the negro race is inferior to the white race" and that this "justifies enslaving him" because otherwise "he would freeze or starve" without the slave master's care).

75 Paul Finkelman, An Imperfect Union: Slavery, Federalism And Comity 137 (1981).

76 Foner, supra note 72 , at 47.

77 Chas. S. Ashley, Governor Ashley's Biography and Messages, in 6 CONTRIBUTIONS to THE HistoricAl Society OF Montana 143, 153 (Historical Society of Montana 1907).

${ }^{78} \mathrm{Id}$.

${ }^{79}$ Many abolitionists shared Ashley's beliefs, including founders of the Republican Party and other prominent members of Congress. See FonER, supra note 72, at 11 (quoting Republican leaders in the 1860s advocating for free labor, which entailed not only the end of slavery, but also an affirmation of the North's labor system that emphasized the common dignity of all workers).

${ }^{80}$ Ashley, supra note 77, at 187-90. 
Section 2 of the Thirteenth Amendment empowers members of Congress to abolish slavery and involuntary servitude, and to remedy what they reasonably believe to be the badges and incidents of slavery. ${ }^{81}$ An examination of judicial and congressional precedent reveals that Congress has wide latitude to define "involuntary servitude" and the badges and incidents of slavery. ${ }^{82}$ Building on Ashley's vision, a Thirteenth Amendment-based vision of equality would include positive rights to work under fair conditions, free from discrimination on the basis of race and gender. That vision begins with economic rights, such as the right to form a union and the right to work free from exploitation. ${ }^{83}$ This vision takes into account the fact that racial, gender, and economic subordination are interconnected in our society. ${ }^{84}$ When members of Congress have acted to enforce the Thirteenth Amendment, they have attempted to further this vision by eliminating barriers to a more just society and facilitating the belonging of outsiders. ${ }^{85}$ They have adopted an anti-subordinating approach to racial, gender, and economic inequality, and adopted affirmative measures to remedy such inequality. ${ }^{86}$ The remainder of this Article analyzes the debates over these affirmative measures to flesh out the meaning of the Thirteenth Amendment's anti-subordination promise.

\section{The ThIRTEENTH AMENDMENT DeBATES}

Even before the end of the Civil War, the Reconstruction Congress definitively abolished the institution of slavery by enacting the Thirteenth Amendment and giving itself the power to enact "appropriate legislation" to enforce the Amendment. ${ }^{87}$ Section 2 was a crucial provision to the Reconstruction Congress. The issue of whether Congress had the power to abolish slavery had been highly controversial during the years leading up to the war, and abolitionist members of Congress had chafed at their inability to act to protect individual rights. ${ }^{88}$ Section 2 was the first constitutional provision to expressly empower Congress to protect rights of belonging. This Section

${ }^{81}$ U.S. Const. amend. XIII; Jones v. Alfred H. Mayer, Co., 392 U.S. 409, 440 (1968); The Civil Rights Cases, 109 U.S. 3, 20 (1883).

${ }^{82}$ See infra Parts III-V.

83 GolubofF, supra, note 6, at 35-38, 55-56 (discussing the New Deal and post-War progressive vision of economic rights and the Workers' Defense Leagues' anti-peonage campaign).

${ }^{84}$ See id. at 79 (discussing the "inter-connectedness of racial and economic injury" in the Jim Crow South).

85 See infra Parts III-V.

86 See infra Parts III-V.

${ }^{87}$ U.S. CONST. amend. XIII, $\S 2$. For an excellent discussion of the history and politics surrounding the adoption of the Thirteenth Amendment, see generally MiCHAEL Vorenberg, Final Freedom: The Civil War, the Abolition of Slavery, and the THIRTEENTH AMENDMENT (2001).

${ }^{88}$ See VORENBERG, supra note 87 , at 41. 
considers the debates over the Thirteenth Amendment and its enforcement power to help discern the meaning of those provisions. ${ }^{89}$ Proponents of the Thirteenth Amendment believed that abolishing slavery was necessary not only to protect the fundamental human rights of slaves, but also to protect workers of all races from both race discrimination and economic exploitation.

\section{A. The Amendment}

From the start of the Civil War, many abolitionists believed that it would result in the end of slavery. ${ }^{90}$ They did not know, however, how that would happen. ${ }^{91}$ The extent of congressional power over slavery had always been highly contested, and uncertainty over whether Congress could end slavery lingered during the War. ${ }^{92}$ Indeed, shortly before the War began Congress came close to amending the Constitution to deprive Congress of the power to abolish slavery. ${ }^{93}$ Lincoln ally Senator William Seward proposed an amendment that would have prohibited adopting any amendment interfering with slavery in the southern states. ${ }^{94}$ It became known as the "Corwin amendment" after Ohio Representative Thomas Corwin, head of the committee created to come up with compromises to avoid war. ${ }^{95}$ The first Thirteenth Amendment carried both Houses of Congress and two state legislatures ratified it. ${ }^{96}$ Nevertheless, the ratification process ended when the Rebels fired upon Fort Sumter. ${ }^{97}$

From the start of the War, abolitionists in Congress felt that ending slavery would be possible and also necessary to win the war. Anti-slavery members of Congress, such as James Ashley, argued that the government's war powers now authorized it to end slavery in support of the war effort. ${ }^{98}$ Ashley argued that states had ceased to be states once they rebelled from the Union, thus

${ }^{89}$ It is important to note that I do not consider the meaning of the Thirteenth Amendment to be confined to either the intent of its Framers, or to the general meaning of the Amendment at the time of its ratification. Indeed, the Framers intended that the meaning of the Amendment change over time, as evidenced by the Framers giving future Congresses broad authority to enforce its provisions. See U.S. CONST. amend. XIII, $\S 2$.

90 See VorenBerg, supra note 87, at 23.

${ }^{91}$ Even after Scott v. Sandford (Dred Scott), 60 U.S. (19 How.) 393 (1856), abolitionists resisted the idea of amending the Constitution. See VorEnBERG, supra note 87, at 14-18. This hesitance was due to the "the widespread belief among all Americans that the constitutional text should remain static." Id. at 15.

92 VORENBERG, supra note 87 , at 41.

${ }^{93} I d$. at $20-22$.

${ }^{94} \mathrm{Id}$. at 20.

${ }^{95} \mathrm{Id}$.

96 Id. at 21.

97 Id. at 22.

98 See Robert F. Horowitz, The Great Impeacher: A Political Biography of James M. AShLEy 64 (1979). 
ceding authority over their land and slaves to the federal government. ${ }^{99}$ Others, including President Lincoln, resisted this "state suicide" theory of Reconstruction. ${ }^{100}$ Eventually, Lincoln came to believe that emancipation of slaves in rebellious territories was necessary for the Union to end the War. ${ }^{101}$ Lincoln's Emancipation Proclamation set in motion the political forces that led to the Thirteenth Amendment. ${ }^{102}$

By the winter of 1863-1864, abolition had become a popular cause in the North, in part because of the South's brutality during the war, and in part because of the bravery of freed blacks on the battlefield. ${ }^{103}$ In December, 1863, Representative Ashley proposed the first constitutional amendment to abolish slavery. ${ }^{104}$ His amendment did not include an enforcement clause. ${ }^{105}$ Ashley may have believed that no such provision was necessary since the Court had twice upheld the Fugitive Slave Acts ${ }^{106}$ even though the Fugitive Slave Clause ${ }^{107}$ lacked an enforcement provision. ${ }^{108}$ This theory is supported by the fact that Ashley accompanied his amendment by a statute enforcing its provisions. ${ }^{109}$ Ashley's statute would have given blacks the right to vote and taken that right away from the rebels. ${ }^{110}$

In the Senate, Charles Sumner proposed his own amendment, which would have declared all people to be "equal before the law."111 The Senate Judiciary Committee rejected that language and instead used the language of the

${ }^{99}$ Les Benedict, James M. Ashley, Toledo Politics, and the Thirteenth Amendment, $38 \mathrm{U}$. TOL. L. REV. 815, 829 (2007).

100 See HoROwITZ, supra note 98 , at 74.

101 VORENBERG, supra note 87, at 27-35.

102 See id. at 1.

103 Id. at 36-37.

104 See Cong. Globe, 38th Cong., 1st Sess. 19, 19 (1863).

105 See id.

106 Fugitive Slave Act of 1850, ch. 60, 9 Stat. 462 (repealed 1864); Fugitive Slave Act of 1793, ch. 7, 1 Stat. 302 (repealed 1864).

107 U.S. Const. art. IV, § 2, cl. 3, repealed by U.S. CONST. amend. XIII.

108 See Prigg v. Pennsylvania, 41 U.S. (16 Pet.) 539, 612 (1842) (upholding the federal Fugitive Slave Act of 1793 even though the Fugitive Slave Clause did not include a provision authorizing congressional enforcement of the Clause); see also Ableman v. Booth 62 U.S. (21 How.) 506, 526 (1859) (reaffirming Prigg and upholding the Fugitive Slave Act of 1850 , which was even broader in scope). During the Reconstruction debate, many members of that Congress cited Prigg to support a broad view of congressional enforcement power. ZiETlow, Enforcing EQuality, supra note 15, at 45-46; see also Robert J. Kaczorowski, Congress's Power to Enforce Fourteenth Amendment Rights: Lessons from Federal Remedies the Framers Enacted, 42 HARV. J. ON LEGIS. 187, 200-01 (2005).

109 VORENBERG, supra note 87, at 49.

${ }^{110} \mathrm{Id}$.

111 Id. at 53. 
Northwest Ordinance ${ }^{112}$ in what eventually became the Thirteenth Amendment. ${ }^{113}$ No record exists of the Judiciary Committee proceedings, but the debates over the 1866 Civil Rights Act indicate that at least some members of the Committee, including Lyman Trumbull and Jacob Howard, believed that their draft accomplished the same goal as Sumner's by extending civil rights to all Americans. ${ }^{114}$

\section{B. The Battle for Approval}

The Senate approved the Thirteenth Amendment on April 8, 1864 by a vote of thirty-eight to six. ${ }^{115}$ The battle in the House of Representatives would prove to be more difficult. ${ }^{116}$ It failed on the first vote ${ }^{117}$ during an uneasy summer in which the war effort seemed to be failing and the question of who would be the Republican nominee for president was still up in the air. ${ }^{118}$ Most Democrats strongly opposed the provision, and with the war effort going badly, supporters of the Amendment were reluctant to say anything that might generate more opposition. ${ }^{119}$ Given the precarious political situation, few members of Congress explained what they thought the Amendment would mean, aside from ending slavery, during that initial debate. ${ }^{120}$ Supporters of the Amendment were notably reticent about the congressional enforcement clause, the first of its kind. ${ }^{121}$ Senate Democrats fiercely attacked the clause, which they said would "invade the states." 22 Republicans said little in response. ${ }^{123}$ They may have assumed that little congressional enforcement would be necessary because states would apply the laws of freedom equally. ${ }^{124}$ Republicans also downplayed the notion of equal citizenship so as not to

112 Northwest Ordinance (1787), reprinted in 1 Stat. 51, 53 n.a (1789) (providing for the governance of territory northwest of the Ohio River and specifically declaring " $[t]$ here shall be neither slavery nor involuntary servitude in the said territory").

113 VORENBERG, supra note 87, at 55.

114 Id. at 55.

$115 \mathrm{Id}$. at 251.

116 Id. at 252.

${ }^{117} \mathrm{Id}$.

118 See id. at 152-53.

119 See id. at 59-72. There were some notable Democrats that supported the Amendment, including Senator Reverdy Johnson of Maryland and Representative James Brooks of New York. Id. at 73-74.

120 See id. at 71.

${ }^{121} I d$. at 132.

${ }^{122}$ Id. (quoting Cong. Globe, 38th Cong., 1st Sess. 2962 (1863) (statement of Sen. Holman)).

123 See id.

124 Id. at 133. 
offend their allies. ${ }^{125}$ They were considerably more outspoken the following year, when they exercised their power to enforce the Amendment.

Once Lincoln was nominated for re-election, he declared his support for the Amendment. ${ }^{126}$ Both parties came to see the measure as a defining issue in the presidential campaign. ${ }^{127}$ Nevertheless, few Republicans adopted it as a campaign issue. ${ }^{128}$ One of the few was James Ashley, who repeatedly affirmed "man's equality before the law" and "boasted ... that he had written the antislavery amendment." 22 Ashley and Lincoln both won their reelection battles, ${ }^{130}$ and Lincoln and his allies declared the election a popular mandate for the anti-slavery Amendment. ${ }^{131}$ Ashley and Lincoln both heavily lobbied for the Amendment. ${ }^{132}$ The final, successful House vote was on January 31, 1865. ${ }^{133}$ Indiana Radical Republican George Julian later said, "It seemed to me I had been born into a new life, and that world was overflowing with beauty and joy." 134

\section{Debates and Meaning}

Enacting the Amendment required support from moderates, and some moderate supporters initially claimed that it did nothing more than free the slaves. ${ }^{135}$ As the debate progressed, however, supporters revealed a growing sense of egalitarianism. ${ }^{136}$ Isaac Arnold claimed that the Amendment was a sign of a "new nation" with liberty and equality before the law as its cornerstone. ${ }^{137}$ One supporter saw the Amendment as "standing on as broad a base as the Declaration of Independence."138 Another said that it was "designed . . . to accomplish . . the abolition of slavery in the United States,

$125 \mathrm{Id}$. at 106.

${ }^{126} \mathrm{Id}$. at 125 .

127 Id. at 142 .

128 Id. at 171.

${ }^{129}$ Id. (quoting James M. Ashley in speech before the Republican Congressional Convention in Toledo, Ohio on May 24, 1864). The boast was inaccurate. Id. Although Ashley was the first to introduce a version of the amendment, Congress ultimately adopted different language. Compare Cong. Globe, 38th Cong., 1st Sess. 19, 19 (1863), with Cong. Globe, 38th Cong., 1st Sess. 1479, 1487-90 (1864).

130 VORENBERG, supra note 87, at 171, 174.

131 Id. at 187.

132 Id. at 180.

133 Cong. Globe, 38th Cong., 2d Sess. 523, 531 (1865).

134 Vorenberg, supra note 87, at 208 (quoting George W. Julian, Political RECOLLECTIONS, 1840 TO 1872, at 240 (1884)).

135 See id. at 86.

136 Id. at 131.

137 Cong. Globe, 38th Cong., 1st Sess. 2977, 2989 (1864).

138 GolubofF, supra note 6, at 18 (describing speech of Godlove S. Orth recorded in Cong. Globe, 38th Cong., 2d Sess. 141-44 (1865)). 
and the political and social elevation of Negroes to all the rights of white men." 139

During the ratification process, members of Congress debated what the abolition of slavery meant for the rights of freed slaves. ${ }^{140}$ Ashley and other Radicals thought that blacks should have the right to vote. ${ }^{141}$ However, most members of Congress agreed that the Thirteenth Amendment was not a source of political rights, but only of civil rights, including economic rights. ${ }^{142}$ Republicans thought that the Amendment "empowered the federal government to ensure that blacks in the former seceded states receive some civil rights, most importantly the right to make contracts and to sue in state and federal courts." 143

Many of the members of the Thirty-eighth Congress had established a long record of opposition to slavery, and reasons for opposing it, that formed the background of their eventual victory. ${ }^{144}$ Abolitionists believed that slavery was an exploitative system of labor that violated fundamental human rights. ${ }^{145}$ Ending slavery would address both problems, but ending slavery alone would not be enough to remedy either the history of racial subordination or the harm that the institution had caused not only to slaves, but to all workers throughout the country. Two groups of abolitionists, anti-slavery constitutionalists and Free Soilers, played the leading roles in the Thirty-eighth and the Reconstruction Congresses. ${ }^{146}$ Anti-slavery constitutionalists argued that slavery violated fundamental human rights protected by the Constitution. ${ }^{147}$ Free Soil abolitionists stressed the economic harm that slavery caused, not only to the enslaved workers in the South, but to all workers throughout the country by depressing wage scales and generally devaluing work. ${ }^{148}$ Debates over the legislation enforcing the Thirteenth Amendment reveal that advocates of both philosophies considered their beliefs to be enshrined in the Constitution as a result of the Amendment.

Anti-slavery constitutionalists claimed that the Constitution should be interpreted consistently with the egalitarian principles of the Declaration of Independence and the Northwest Ordinance, and that ambiguities should be

139 Cong. Globe, 38th Cong., 1st Sess. 2987.

140 VORENBERG, supra note 87, at 188-90.

141 See Michael Les Benedict, A Compromise of Principle: Congressional REPUBLICANS AND RECONSTRUCTION 1863-1869, at 23-27 (1974).

142 VORENBERG, supra note 87, at 190.

143 Id. at 222.

144 See FonER, supra note 72, at 9-11.

145 See id. at 288.

146 See infra Part II.C.

147 See William M. Wiecek, The Sources of Antislavery Constitutionalism in AMERICA, 1760-1848, at 259-63 (1977).

148 See FONER, supra note 72, at 58-61. 
resolved consistently with those egalitarian principles. ${ }^{149}$ They also claimed that the Constitution authorized Congress to prevent the extension of slavery. ${ }^{150}$ The latter argument was based on three provisions of the Constitution $^{151}$ : the provisions authorizing Congress to regulate the territories and admit new states, ${ }^{152}$ the Article IV Guaranty Clause, which guarantees a republican form of government to the states, ${ }^{153}$ and the provision authorizing Congress to ban the importation of slaves. ${ }^{154}$ Thus, anti-slavery constitutionalists relied on the provisions of the original Constitution that protected individual rights to support their claim that slavery was unconstitutional.

The Free Soil abolitionists voiced an economic critique - slavery caused the degradation of all labor and allowing expansion into new territory would harm white laborers who would effectively be barred from settling there. ${ }^{155}$ For example, James Ashley argued that slavery was a class issue, an institution of the southern aristocracy that facilitated the subordination of white workers who could not afford to own slaves and therefore competed with slaves in the labor market. ${ }^{156}$ Thus, Ashley believed that class antagonism in the South was "the real point of danger to the ruling class of the South." 157 Prominent Ohio Senator Salmon Chase agreed that the problem with slavery was "that it violated the free-labor ideal of workers exchanging their labor for appropriate wages." 158

The degrading impact of slavery on all laborers formed the central ideology of the Free Soil Party, whose members were among the founders of the Republican Party in 1856. ${ }^{159}$ Moderate and conservative Republicans emphasized the impact of slavery on white workers because they believed this argument would be more persuasive than the moral argument. ${ }^{160}$ In Congress, Free Soilers extolled the value of economic rights, including the freedom to enter into contracts and own property. ${ }^{161}$ Some claimed all citizens were

149 WIECEK, supra note 147 , at 112 . See generally LySANDER SPOONER, THE UnCONSTITUTIONALITY OF SLAVERY (Burt Franklin 1965) (1860).

${ }^{150}$ WIECEK, supra note 147, at 111.

${ }^{151}$ Id. at 111-25.

152 U.S. CONST. art. IV, § 3, cl. 1-2.

153 Id. $\S 4$.

${ }^{154}$ Id. art. I, § 9, cl. 1; see also WIECEK, supra note 147, at 111-25.

155 See FONER, supra note 72, at 57-58.

156 See id. at 120.

157 CONG. Globe, 36th Cong. 1st Sess. 361, 364 (1860), cited in FonER, supra note 72, at 120.

158 VORENBERG, supra note 87, at 14.

159 FONER, supra note 72, at 58-61.

${ }^{160} \mathrm{Id}$. at 60-62.

161 See id. at 17. 
entitled to these economic rights. ${ }^{162}$ This ideology was later reflected in the 1866 Civil Rights Act, which protected economic rights, including rights to contract, own property, and have access to courts to protect property, and linked those rights to citizenship. ${ }^{163}$

The debates over the Thirteenth Amendment enforcement power reflect antebellum abolitionist thought, including the emphasis on fundamental human rights, the Free Soil labor tradition, and the importance of congressional enforcement power. The Thirteenth Amendment provided Congress with the power to enforce a broad source of fundamental human rights. ${ }^{164}$ Some leaders in the Reconstruction Congress believed that abolishing slavery was essential not only for remedying race discrimination, but also for remedying the negative economic impact slavery had on all workers. ${ }^{165}$ The Republican Party had been formed based on an ideology of free labor, and members of that party believed strongly in workers having autonomy and mobility. ${ }^{166}$ They believed that ending slavery would play an important role in preventing the race to the bottom and enhancing the belonging of workers throughout the country. ${ }^{167}$ Section 2 of the Thirteenth Amendment gave members of the Reconstruction Congress the power to make this vision a reality.

\section{The Scope of the Enforcement Power and Judicial Deference}

During the debates over enforcement legislation, members of the Reconstruction Congress made it clear that they believed that Section 2 provided them with broad enforcement power. Senator Trumbull and his colleagues believed that they had authority to determine the scope of their power notwithstanding the Court's ruling to the contrary. ${ }^{168}$ Members of Congress repeatedly invoked the broad test for congressional power provided in $M^{\prime}$ Culloch $v$. Maryland ${ }^{169}$ to illustrate the meaning of the word

162 See id. at 290.

163 Civil Rights Act of 1866, ch. 31, 14 Stat. 27 (codified as amended at 42 U.S.C. $\S \S$ 1981-1983 (2006)).

164 See Alexander Tsesis, The Thirteenth Amendment and American Freedom: A LEgAL History 34 (2004) (arguing that ratifying the Thirteenth Amendment in 1865 created an obligation to "preserve and further liberty rights").

165 Lea S. VanderVelde, The Labor Vision of the Thirteenth Amendment, 138 U. PA. L. REV. 437, 437-41 (1989).

166 See FONER, supra note 72, at 16-17.

167 See id. at 47.

168 This belief is evidenced by Section 1 of the 1866 Act, which declared that all persons born within the jurisdiction of the United States were United States citizens. Civil Rights Act of 1866, ch. 31, 14 Stat. 27 (1866) (codified as amended at 42 U.S.C. §§ 1981-1983). This provision directly conflicted with the Court's ruling in Dred Scott that people of African descent could not be American citizens. Scott v. Sandford (Dred Scott), 60 U.S. (19 How.) 393, 454 (1856).

16917 U.S. (4 Wheat.) 316 (1819). 
"appropriate" in Section 2.170 Trumbull explained, "What that 'appropriate legislation' is, is for Congress to determine, and nobody else." 171 Responding to President Johnson's veto of an act in 1865, Representative Cook claimed that Section 2 meant "that Congress shall have power to secure the rights of freemen to those men who had been slaves. It meant, secondly, that Congress should be the judge of what is necessary for the purpose of securing to them those rights." 172 Thus, it is clear that the Framers of the Thirteenth Amendment intended Congress to have substantial autonomy to enforce its promise. ${ }^{173}$

In Jones v. Alfred H. Mayer, Co., the Court followed the Thirty-eighth Congress's lead and deferred to the legislature as it upheld a provision of the 1866 Civil Rights Act prohibiting race discrimination in real estate transactions as a valid exercise of the Section 2 power. ${ }^{174}$ Citing the Civil Rights Cases, the Court noted that Congress's Section 2 power extends to eliminating the "badges and incidents of slavery." 175 The Court observed, "Surely Congress has the power under the Thirteenth Amendment rationally to determine what are the badges and incidents of slavery, and the authority to translate that determination into effective legislation." 176 Therefore, the Court applied a highly deferential standard to congressional enforcement of the Thirteenth Amendment.

170 Cong. Globe, 42d Cong., 1st Sess. 686, 695 (1871) (statement of Sen. Thurman) (stating that Section 2 is "not a particle broader than the clause in the original Constitution that Congress shall have power to pass all laws necessary and proper, and this very word 'appropriate' is derived from the opinion of Judge Marshall in McCulloch vs. Maryland"); Cong. Globe, 39th Cong., 1st Sess. 1115, 1118 (1866) (statement of Rep. Wilson).

171 Cong. Globe, 39th Cong., 1st Sess. 39, 43 (1865) (statement of Sen. Trumbull).

172 Cong. Globe, 39th Cong., 1st Sess. 1115, 1124 (statement of Rep. Cook).

173 The question of the proper relationship between courts and Congress arose a couple of years later when Congress considered a bill that would have prohibited the ongoing practice of state courts imposing servitude as a sentence for a crime. See Cong. GLOBE, 39th Cong., 2d Sess. 344, 344-45 (1867). Opponents of the bill argued that Congress lacked the power to overturn the state court's sentencing orders. See id. at 345 (statement of Rep. Finck). In response, Representative John Kasson insisted, "I do assert that Congress, as the power originally creating the clause, has the right to construe it, and that there is not a loyal tribunal in this country that will dare to treat with disrespect the construction given by this body to this clause of the Constitution." Id. (statement of Rep. Kasson). While Kasson conceded that the Supreme Court would have the final say on constitutional matters, he believed that the Court would and should defer substantially to Congress. Id.

174 Jones v. Alfred H. Mayer, Co., 392 U.S. 409, 439 (1968) (holding that the authority of Congress to enforce the Thirteenth Amendment by "appropriate legislation" includes the power to eliminate all racial barriers to the acquisition of real and personal property).

175 Id. at 439 (quoting The Civil Rights Cases, 109 U.S. 3, 20 (1883)).

176 Id. at 440. 
Since Jones, the Court has continued to defer to Congress, despite rulings limiting other congressional powers. ${ }^{177}$ Recently, in CBOCS West, Inc. v. Humphries, the Court held that 42 U.S.C. $\S 1981$, a Section 2 based statute that prohibits race discrimination in contracts, encompasses a complaint of retaliation against a person who has complained about race discrimination against another employee. ${ }^{178}$ Justice Breyer, writing for the majority, relied on cases in which the Court had broadly interpreted $\S 1981$ and another provision of the 1866 Civil Rights Act, 42 U.S.C. $\S 1982$, that prohibits race discrimination in real estate transactions. ${ }^{179}$ The Court pointed out that Congress had overruled its earlier interpretation that $\S 1981$ did not to apply to discrimination after the making of a contract ${ }^{180}$ by amending $\S 1981$ in the 1991 Civil Rights Act. ${ }^{181}$ In broadly interpreting $§ 1981$, the Court relied on stare decisis and congressional deference. ${ }^{182}$ Both the Court's ruling and its reasoning make it appear likely that the Court will continue to defer to Section 2 , allowing Congress substantial authority to use it to expand rights of belonging. By substantially deferring to Congress, the Court has left ample room for the legislature to enforce the Thirteenth Amendment.

\section{ENFORCING THE AMENDMENT - RECONSTRUCTION}

This Part explores congressional debates over legislation enforcing the Thirteenth Amendment as members of Congress fleshed out the meaning of the Amendment. By the time the Amendment became law in December 1865, a consensus had developed that the Thirteenth Amendment at least protected people's rights to life, liberty, and property. ${ }^{183}$ During these debates, an antisubordination philosophy emerged that combined the abolitionists' concern with protecting fundamental human rights (including the right to travel, the right to enter into contracts, and the right to be free of race discrimination) with concerns about remedying the economic exploitation of all workers. The debates reveal that the members of the Reconstruction Congress believed that the Thirteenth Amendment itself transformed freed slaves into individuals with rights equal to white citizens, bestowing upon them positive rights - that their

177 See CBOCS W., Inc. v. Humphries, 128 S. Ct. 1951, 1955 (2008) (holding that 42 U.S.C. $§ 1981$ (2006) encompasses retaliation claims); Runyon v. McCrary, 427 U.S. 160, 172 (1976) (holding that 42 U.S.C. $\$ 1981$ reaches private conduct).

178 CBOCS W., 128 S. Ct. at 1954-55.

179 See id. at 1955-56.

180 Patterson v. McLean Credit Union, 491 U.S. 164, 171 (1989).

181 CBOCS W., 128 S. Ct. at 1957 (citing Civil Rights Act of 1991, Pub. L. No. 102-166, $\S 101,105$ Stat. 1071 (codified in scattered sections of 42 U.S.C.)).

182 Id. at 1958-59.

183 See VorenBERG, supra note 87, at 232. 
experience of freedom would be the opposite of slavery. ${ }^{184}$ The legislation enacted by this Congress offers a concrete example of their vision of freedom.

Members of the Reconstruction Congress used their power to remedy two aspects of the institution of slavery. The first aspect was the system of white supremacy that southerners used to justify slavery. ${ }^{185}$ The second aspect was the exploitative labor practices exemplified by slave masters' ownership of workers, but also perpetuated more broadly by the practice of peonage and other forms of involuntary servitude unrelated to race. ${ }^{186}$ Reconstruction Congressmen understood the synthesis of race and economic exploitation that underlay the system they sought to abolish and, moreover, believed that they had broad authority to recognize that synthesis and enact measures to remedy its legacy. ${ }^{187}$

The members of the Reconstruction Congress enforcing the Thirteenth Amendment adopted an anti-subordination theory of equality as they acted to carry out the Amendment's promise of freedom and equality. They relied on the Thirteenth Amendment as a source of power to require racial equality in the exercise of fundamental rights, to define those rights broadly, and to make them enforceable against both state and private actors. ${ }^{188}$ They also directly addressed the exploitation of workers by outlawing not just slavery, but also peonage and other "slavery like" employment practices. ${ }^{189}$ They believed that affirmative measures to end race discrimination and raise the status of all workers were necessary to enforce the fundamental rights of freed slaves and others in our society. ${ }^{190}$ The statutes they enacted are evidence that members of the Reconstruction Congress acknowledged the connection between racial and economic exploitation, and attempted to remedy both. Their antisubordination theory of equality encompassed both liberty and equality rights, because for freed slaves, liberty in the economic sphere, including liberty to enter into contracts, choose one's employer, and travel to find family members and employers, was necessary for racial equality.

184 Jacobus tenBroek, Thirteenth Amendment to the Constitution of the United States: Consummation to Abolition and Key to the Fourteenth Amendment, 39 CAL. L. REV. 171, 171-80 (1951).

185 To remedy this aspect of slavery, members of the Reconstruction Congress enacted statutes prohibiting discrimination on the basis of race. See infra Part III.A.

186 See FONER, supra note 72, at 38-39, 58-59. Acting on this belief, members of the Reconstruction Congress enacted legislation prohibiting peonage without reference to race. See infra Part III.B.

187 See infra Parts III.A-B.

188 See infra Part III.A.

189 See infra Part III.B.

190 See infra Parts III.A-B. 


\section{A. Civil Rights Legislation}

To the members of the Reconstruction Congress, the Amendment did more than just abolish slavery - it enabled congressional enforcement of rights of belonging. As Senator Lyman Trumbull explained, "It is idle to say that a man is free who cannot go and come at pleasure, who cannot buy and sell, who cannot enforce his rights. These are rights which the first clause of the constitutional amendment meant to secure to all."191 Senator William Sherman agreed, noting that the Thirteenth Amendment was "not only a guarantee of liberty to every inhabitant of the United States, but an express grant of power to Congress to secure this liberty by appropriate legislation." ${ }^{192}$ The Reconstruction Congress relied on the Thirteenth Amendment to enact legislation to end the subordination that resulted from the racially-based denial of fundamental rights and the brutal economic exploitation of slavery.

Members of the Reconstruction Congress understood that the task they had taken on would be difficult, even overwhelming. As Senator Jacob Howard pointed out during the debate over the 1866 Civil Rights Act,

We are told that the amendment simply relieves the slave from the obligation to render service to his master. What is a slave in contemplation of American law, in contemplation of the laws of all of the slave States? We know full well . . . [h]e had no rights, nor nothing which he could call his own. He had not the right to become a husband or a father in the eye of the law, he had no child, he was not at liberty to indulge the natural affections of the human heart for children, for wife, or even for friend. He owned no property, because the law prohibited him. He could not take real or personal estate either by sale, by grant, or by descent or inheritance. He did not own the bread he earned and ate. He stood upon the face of the earth completely isolated from the society in which he happened to be .... ${ }^{193}$

Remedying this situation would require strong, affirmative measures. Even before the Thirteenth Amendment became law, Congress established the Freedman's Bureau and began to consider civil rights legislation. ${ }^{194}$ Once the Amendment became law, Congress used its Section 2 power to prohibit kidnapping people for enslavement, enact far-reaching civil rights statutes, and abolish slavery and the slavery-like practice of peonage. ${ }^{195}$

191 Cong. Globe, 39th Cong., 1st Sess. 39, 43 (1865).

192 Id. at 41.

193 Cong. Globe, 39th Cong., 1st Sess. 497, 504 (1866).

194 See TSESIS, supra note 164, at 52-53; VORENBERG, supra note 87, at 83-84.

195 See Slave Kidnapping Statute, ch. 86, 14 Stat. 50 (1866) (codified as amended at 18 U.S.C. $\$ 443$ (2006)); Anti-Peonage Act, ch. 187, 14 Stat. 546 (1867) (codified as amended at 18 U.S.C. § 1581 and 42 U.S.C. § 1994 (2006)); Joint Resolution to Aid in Relieving from Peonage Women and Children of the Navajo Indians, H.R. Con. Res. 83, 40th Cong. (1868). The Slave Kidnapping Statute had special symbolic significance since it overruled 
The primary goal of those enforcing the Thirteenth Amendment was to place freed slaves on an equal footing to their white compatriots with regard to their right to engage in economic relationships. ${ }^{196}$ Slaves had been unable to enter into contracts, purchase property, or engage in any economic transactions. ${ }^{197}$ They also lacked the ability to form legal families, and consequently they were at constant risk of losing their children, spouses, or other loved ones. ${ }^{198}$ Representative E.C. Ingersoll of Illinois believed that the Thirteenth Amendment would

secure to the oppressed slave his natural and God-given rights . . . [A] right to live, and live in a state of freedom ... [A] right to till the soil, to earn his bread by the sweat of his brow, and to enjoy the rewards of his own labor ... [A] right to the endearments and enjoyment of family ties . ... 199

Hence, members of the Reconstruction Congress believed that the Thirteenth Amendment authorized Congress to enforce what they considered to be fundamental human rights. These rights included the ability to engage in the economic arena free of the fetters of race discrimination and economic exploitation.

Opponents of these measures objected that the 1866 Civil Rights Act exceeded Congress's Section 2 power because the Thirteenth Amendment was solely intended to end slavery, not to protect individual rights. ${ }^{200}$ In their response to these objections, proponents of the Act made it clear that they equated freedom with fundamental human rights, and that they believed that Section 2 empowered them to make this vision a reality. ${ }^{201}$ Members of

the hated Fugitive Slave Acts that had authorized the kidnapping of fugitive slaves. 18 U.S.C. $\S 443$.

196 The best example of this approach is the 1866 Civil Rights Act, ch. 31, 14 Stat. 27 (codified as amended at 42 U.S.C. $\S \S 1981-1983$ ).

197 See, e.g., William Goodell, The American Slave Code, in Theory and Practice 89 (New York, American and Foreign Anti-Slavery Society 1853) (surveying Slave Codes in southern states and concluding that "slaves can possess nothing" because "being property themselves, they can own no Property, nor make any Contracts"). Since marriage is a form of contract; therefore no slave marriage had legal standing. Id.

${ }^{198} I d$.

199 Cong. Globe, 38th Cong., 1st Sess. 2989, 2990 (1864).

200 See Cong. Globe, 39th Cong., 1st Sess. 497, 499 (1866) (statement of Sen. Cowan) ("That amendment, everybody knows and nobody dare deny, was simply made to liberate the negro slave from his master. That is all there is of it."); Cong. Globe, 39th Cong., 1st Sess. 474, 476 (statement of Sen. Saulsbury) ("It does not of itself declare, and human ingenuity cannot torture it into meaning that the Congress of the United States shall invade the States and attempt to regulate property and personal rights within the States any further than refers simply and solely to the condition and status of slavery.").

201 See, e.g., Cong. Globe, 39th Cong., 1st Sess. 1151, 1152 (Statement of Rep. Thayer); Cong. Globe, 39th Cong., 1st Sess. 474, 504 (Statement of Sen. Howard); Cong. Globe, 39th Cong., 1st Sess. 595, 602 (Statement of Sen. Lane). 
Congress overwhelmingly adopted the view of the proponents, approving the 1866 Civil Rights Act and all other Reconstruction measures by well over the two-thirds margin needed to overcome the veto of President Johnson. ${ }^{202}$ To ensure that they had the power to enforce these rights against state governments, they also enacted the Fourteenth Amendment. ${ }^{203}$ A century later, the Supreme Court agreed with the vast majority of the Reconstruction Congress and upheld sections of the 1866 Act as valid enforcement of the Thirteenth Amendment. ${ }^{204}$

\section{The 1866 Civil Rights Act}

Immediately after the Amendment became law on December 18, 1865, 205 the Amendment's sponsor in the Senate, the well-respected lawyer Lyman Trumbull, introduced a bill to enforce its provisions, which became the 1866 Civil Rights Act. ${ }^{206}$ The Act provided that all persons born in the United States would be citizens and would enjoy the same right "to make and enforce contracts, to sue, be parties, and give evidence, to inherit, purchase, lease, sell, hold, and convey real and personal property, and to full and equal benefit of all laws and proceedings for the security of person and property, as is enjoyed by white citizens." 207

During the debate over the 1866 Civil Rights Act, members of the Reconstruction Congress discussed the scope of the Section 2 enforcement power. ${ }^{208}$ By this time, those members of Congress who initially thought that congressional enforcement of the Amendment might not be necessary, already had to confront the oppressive Black Codes enacted by former slave states, which led them to embrace a broad reading of the enforcement power. ${ }^{209}$ Even before the Secretary of State certified the Amendment, Senator Trumbull made it clear that he believed Section 2 enabled Congress to protect the fundamental rights of not only the newly freed slaves, but all persons within their jurisdiction. ${ }^{210}$ Senator Trumbull explained in an earlier debate, "The second clause of that amendment was inserted for . . . the purpose . . . of preventing State Legislatures from enslaving, under any pretense, those whom the first

202 See Civil Rights Act of 1866, ch. 31, 14 Stat. 27 (codified as amended at 42 U.S.C. $\S \S$ 1981-1983 (2006)).

203 See infra notes 216, 223 and accompanying text.

204 See Jones v. Alfred H. Mayer, Co., 392 U.S. 409, 413 (1968).

205 See Vorenberg, supra note 87, at 233 (describing Secretary of State Seward's proclamation declaring the amendment ratified).

206 See S. 61, 39th Cong. (1866).

207 Civil Rights Act of 1866, ch. 31, 14 Stat. 27, 27 (codified as amended at 42 U.S.C. $\S \S$ 1981-1983).

208 See Cong. Globe, 39th Cong., 1st Sess. 594, 594-607 (1866).

209 See ERIC Foner, ReCONSTRUCTION: AmERICA's UnFINISHEd REVOLUTION 1863-1877, at 208-09 (Perennial Classics 2002) (1988).

210 See Cong. Globe, 39th Cong., 1st Sess. 39, 43 (1865) (statement of Sen. Trumbull). 
clause declared should be free." 211 Senator Lane agreed that the Thirteenth Amendment

made [it] your especial duty by the second section of that amendment, by appropriate legislation, to carry out that emancipation. . . . I do not consider that the second section of that amendment does anything but declare what is the duty of Congress, after having passed such an amendment to the Constitution of the United States, to secure them in all their rights and privileges. ${ }^{212}$

Lane explained that the bill would "give effect to the proclamation of emancipation and to the constitutional amendment." 213 Thus, these members of the Reconstruction Congress, both of whom had supported the Thirteenth Amendment, explained that they believed freedom meant more than the end of slavery. To them, freed slaves were entitled to the fundamental rights needed to end the years of subordination they had suffered under the yoke of slavery.

The best evidence of this view is the Citizenship Clause of the 1866 Act, which provided that all citizens of the United States "of every race and color . . . shall have the same right, in every State or Territory in the United States . . . to inherit, purchase, lease, sell, hold and convey real and personal property . . . as is enjoyed by white citizens." 214 The enactment of this clause indicates that members of Congress believed that by ending slavery, the Thirteenth Amendment had overturned the Court's ruling in Dred Scott that African Americans could not be citizens. ${ }^{215}$ Eventually, the Reconstruction Congress explicitly ratified their view that freed slaves were citizens with the Citizenship Clause of the Fourteenth Amendment. ${ }^{216}$

As the Citizenship Clause indicates, supporters of the 1866 Act wanted it to implement monumental change, transforming former slaves into equal citizens. Senator Howard explained that with "respect to all civil rights . . there is to be hereafter no distinction between the white race and the black race."217 Senator Henry Lane agreed that the goal of the Act was to ensure "[t]hat these freedmen shall be secured in the possession of all the rights, privileges, and immunities of freemen; in other words, that we shall give effect to the proclamation of emancipation and to the constitutional amendment." 218

211 Id.

212 Cong. Globe, 39th Cong., 1st Sess. 594, 602 (statement of Sen. Lane).

213 Id.

214 Civil Rights Act of 1866, ch. 31, § 1, 14 Stat. 27, 27 (codified as amended at 42 U.S.C. $\S 1981-1982$ (2006)).

215 See Scott v. Sandford (Dred Scott), 60 U.S. (19 How.) 393, 454 (1856).

${ }^{216}$ U.S. Const. amend. XIV, $\S 1$. Congress added the Fourteenth Amendment Citizenship Clause at the last minute, in part because many members did not think it necessary. See Cong. Globe, 39th Cong., 1st Sess. 2764, 2768; Cong. Globe, 39th Cong., 1st Sess. 2890, 2890.

217 Cong. Globe, 39th Cong., 1st Sess. 474, 504 (statement of Sen. Howard).

${ }^{218}$ Cong. Globe, 39th Cong., 1st Sess. 592, 602 (statement of Sen. Lane). 
Representative Thayer echoed Lane's theme, announcing that "[t]he sole purpose of the bill is to secure to that class of persons the fundamental rights of citizenship . . . those rights which are common to the citizens of all civilized States; those rights which secure life, liberty and property." ${ }^{19}$ He explained that the Thirteenth Amendment was intended not only to abolish slavery, but also to abolish and destroy "all features of slavery which are oppressive in their character, which extinguish the rights of free citizens, and which unlawfully control their liberty." 220

Opponents of the 1866 Act argued that Section 2 was insufficient to empower Congress to enact such a statute because that power was limited to the simple task of ending the institution of slavery. ${ }^{221}$ Since most of those expressing a restrictive view of the enforcement power had opposed the Thirteenth Amendment to begin with, the Republican majority largely disregarded their critique. 222 However, that majority took more seriously the concerns of their fellow Republican, Representative John Bingham. Bingham supported the Act on principal but his doubts over congressional authority to enact it inspired him to propose the Fourteenth Amendment to unequivocally empower Congress to enact a wider range of civil rights legislation. ${ }^{223}$ Representative Bingham was well respected, and his fellow Republicans acted quickly to ratify what they considered to be "his" Fourteenth Amendment. ${ }^{224}$ However, few of them joined him in voting against the Act, which was approved by an overwhelming majority over the veto of President Johnson. ${ }^{225}$

Two sections of the 1866 Civil Rights Act - now codified as 42 U.S.C. $\S$ 1981, which includes its prohibition on race discrimination in the making and enforcing of contracts, and 42 U.S.C. § 1982, which prohibits race discrimination in real estate transactions - provide significant remedies for people who are victims of private race discrimination when they attempt to

${ }^{219}$ Cong. Globe, 39th Cong., 1st Sess. 1151, 1152 (statement of Rep. Thayer).

${ }^{220} I d$.

221 See supra note 200.

222 See Jones v. Alfred H. Mayer, Co., 392 U.S. 409, 439 (1968) (observing that many of those who opposed passage of the Act on the ground that the Thirteenth Amendment only authorized Congress to end slavery, had earlier opposed the Amendment on the ground that it would give Congress "virtually unlimited power to enact laws for the protection of Negroes in every State").

${ }^{223}$ Cong. Globe, 39th Cong., 1st Sess. 1033, 1033-34 (statement of Rep. Bingham); see also Michael Kent Curtis, No State Shall Abridge: The Fourteenth Amendment AND the Bill of Rights 82 (1986) (citing Cong. Globe, 39th Cong., 1st Sess. 1291); Zietlow, ENForcing EQuality, supra note 15, at 48 (citing Cong. Globe, 39th Cong., 1st Sess. 1291).

224 ZieTlow, EnForcing EQuALity, supra note 15, at 48-49.

${ }^{225} I d$. at 48. After Congress ratified the Fourteenth Amendment, Congress reenacted the provisions of the 1866 Act as part of the 1870 Enforcement Act, ch. 114, § 18, 16 Stat. 140, 144 (codified as amended at 18 U.S.C. $§ 242$ and 42 U.S.C. $§ 1985$ (2006)). 
engage in basic economic transactions. ${ }^{226}$ It is also clear that members of this Congress did not see the rights of freedom as limited to economic rights. While they were divided over whether those rights included the right to vote, ${ }^{227}$ they agreed that the right to sue in court was fundamental and protected it in their first civil rights statute. 228

In Jones v. Alfred H. Mayer, Co., the Court agreed with the majority of the Reconstruction Congress and upheld $\S 1982$ as authorized by Section 2 of the Thirteenth Amendment. ${ }^{229}$ In that case, an African American couple sued a real estate developer alleging that he had refused to sell them a home because of their race, in violation of 42 U.S.C. $\S 1982 .{ }^{230}$ The Court held that the statute was not limited to state action because the members of the Reconstruction Congress "plainly meant to secure [the] right [to purchase real estate] against interference from any source whatever, whether government or private." 231 The Court found that Congress's determination that racial discrimination in real estate transactions was a "badge and incident of slavery" was rational because "the exclusion of Negroes from white communities became a substitute for the Black Codes" that members of the Reconstruction Congress intended the statute to abolish. ${ }^{232}$ Thus, with this ruling, the Court ratified the anti-subordination mission of the Reconstruction Congress.

\section{The 1871 Enforcement Act}

One of the most far-reaching civil rights acts ever enacted by Congress, the 1871 Enforcement Act (also known as the "Ku Klux Klan Act"), 233 was also based in the Section 2 power. ${ }^{234}$ The statute imposed civil and criminal penalties on state and private actors for conspiracies to prevent a person from

${ }^{226}$ In 1968, Congress supplemented $\S 1982$ with the Fair Housing Act, Pub. L. No. 90284, 82 Stat. 81 (codified as amended at 42 U.S.C. $§ \S 3601-3631$ ).

227 In July, 1867, Senator Charles Sumner proposed a bill which would extend Negro suffrage to non-rebel states, arguing that the Act fell within Congress's power to enforce the Thirteenth Amendment. See Cong. Globe, 40th Cong., 1st Sess. 610, 614 (1867) (statement of Sen. Sumner). The bill failed by a vote of twelve to twenty-two. Id.

${ }^{228}$ See Civil Rights Act of 1866, ch. 31, 14 Stat. 27, 27 (codified as amended at 42 U.S.C. $\S$ 1981-1983).

229 Jones v. Alfred H. Mayer, Co., 392 U.S. 409, 413 (1968).

${ }^{230} I d$. at 412 . For an excellent discussion of the history of Jones, see Miller, supra note 27 , at $1037-39$.

231 Jones, 392 U.S. at 424.

${ }^{232}$ Id. at 442.

2331871 Enforcement Act, 17 Stat. 13, 13-15 (codified as amended in scattered sections of 18 U.S.C. and 42 U.S.C.).

${ }^{234}$ While some members of Congress believed that the Act fell within their power to enforce the Fourteenth Amendment, others argued that it fell within the Thirteenth Amendment enforcement power. See infra notes 251-64 and accompanying text. The Supreme Court eventually upheld the Act as a valid exercise of Congress's Section 2 power. Griffin v. Breckenridge, 403 U.S. 88, 105 (1971). 
exercising "any right or privilege of a citizen of the United States." 235 The statute was a reaction to the race-based violence that plagued the southern states as Reconstruction progressed. ${ }^{236}$ When freed slaves attempted to exercise their new rights, they often confronted violent opposition from their white neighbors. ${ }^{237}$ The Ku Klux Klan formed and engaged in organized violence aimed at suppressing the rights of newly freed slaves and intimidating them and those whites who supported them. ${ }^{238}$ By 1871, rampant violence in southern states had convinced members of Congress that the federal authorities could not maintain order without stronger enforcement provisions. ${ }^{239}$ Supporters intended the 1871 Enforcement Act to give the federal government more power to enforce the new rights that it had created, including the 1866 Civil Rights Act, establishing a broad federal protective shield over the civil rights of persons within Congress's jurisdiction. ${ }^{240}$ The statute empowered the federal government to stop private acts that subordinated people through the use of violence to stop them from exercising their fundamental rights. ${ }^{241}$

On March 20, 1871, Representative Butler of Massachusetts introduced the Act, calling it a bill "to protect loyal and peaceable citizens in the South in the full enjoyment of their rights, persons, liberty and property." 242 The Act created civil and criminal penalties for conspiracies to deprive a person of exercising "any right or privilege of a citizen of the United States."243 Speaking in support of the Act, Senator Ames explained that Republicans in the South had suffered from violence and petitioned for this relief. ${ }^{244} \mathrm{He}$ pointed out that the violence had been particularly bad leading up to elections and argued that it was intended to disempower the Republican Party in the South by murdering local party leaders. ${ }^{245}$ He claimed that when

this "white man's party" shall dominate, should it ever, you will see class legislation so harsh and so cruel as either to force the colored people into

\footnotetext{
23542 U.S.C. $\$ 1985(3)$.

236 Xi Wang, The Making of Federal Enforcement Laws, 1870-1872, 70 CHI.-Kent L. REV. 1013, 1048-49 (1995). been subjected to every kind of outrage, from murder and whippings to the meanest insults man can offer to his fellow-man," leading Republicans to "urge on Congress the necessity of prompt and thorough measures to suppress outrage and violence in all parts of the State"). ${ }^{245} I d$.
} 
a serfdom worse than slavery, or else a condition of affairs which will force you to take the step you are now asked to take. ${ }^{246}$

Thus, Ames believed that the legislation was necessary for the political empowerment of former slaves and anyone else who dared to challenge the system of white supremacy that had been the basis for slavery. White supremacy was fast taking hold again of the South, and would eventually provide the basis for the subordination of blacks under Jim Crow. ${ }^{247}$ The 1871 Enforcement Act was Congress's last attempt to stop this re-entrenchment.

Opponents of the 1871 Enforcement Act argued that it was beyond Congress's power because the Fourteenth Amendment did not permit Congress to remedy private violence. ${ }^{248}$ Others argued that the Thirteenth Amendment could only address state laws, because only states had the power to "remand or attempt to remand" a person to slavery. ${ }^{249}$ Members of Congress ultimately rejected this view by voting in favor of the Act. ${ }^{250}$ Proponents relied on both the Thirteenth and Fourteenth Amendments as justifications for the Act. ${ }^{251}$ Representative Shellaburger, the chief sponsor of the bill, explained that the Act was modeled on the second section of the 1866 Civil Rights Act ${ }^{252}$ and that the 1866 Act was enacted to enforce the Thirteenth Amendment. ${ }^{253}$ If the 1866 Act was constitutional, he argued, then so was his bill. ${ }^{254}$ In Shellaburger's opinion, the Thirteenth Amendment "reversed and overthrew the State constitutions creating slavery and prohibited the States from 'denying' the slaves citizenship" and Section 2 gave Congress power to enforce this first provision by “'appropriate legislation;' or, in other words, to enforce the rights of citizenship to which the slave was admitted by act of his emancipation." 255

246 Id. at 197.

247 See Wang, supra note 236, at 1048-49.

248 See, e.g., Cong. Globe, 42d Cong., Spec. Sess. 206, 208 (1871) (statement of Rep. Blair) ("The language [of the Fourteenth Amendment] is 'No State' shall do this or that. Individuals nor a combination of individuals are mentioned, and yet they are to be brought under the provisions of the bill and the 'State' is to be exempted."); ConG. GlobE, 42d Cong., Spec. Sess. 46, 46 (statement of Rep. Kerr); Cong. Globe, 42d Cong., 1st Sess. 218, 222 (1871) (statement of Sen. Thurman) ("[W]ill anybody tell me where he can find in this fourteenth amendment any power to invade the States and take the entire punishment of crime, the entire jurisdiction of crimes committed within a State, into the hands of Congress?").

249 Cong. Globe, 42d Cong., Spec. Sess. 206, 208 (statement of Rep. Blair).

${ }^{250}$ Cong. Globe, 42d Cong., 1st Sess. 808, 831.

251 See, e.g., Cong. Globe, 42d Cong., Spec. Sess. 67, 68 (statement of Rep. Shellabarger).

${ }^{252}$ Id. at 68-69.

253 Id.

${ }^{254} \mathrm{Id}$.

255 Id. 
Representative John Bingham agreed with Shellaburger that the 1871 Enforcement Act fell within Congress's power to enforce the Thirteenth Amendment. ${ }^{256}$ He pointed out that the Thirteenth Amendment imposed a new limitation on the states and gave a new power to Congress. ${ }^{257}$ It prohibited states from allowing slavery, and authorized Congress to "make it a felony punishable by death to reduce any man ... endowed with immortal life, into a thing of trade, an article of merchandise." 258 Bingham continued, "In such a case the nation would inflict the penalty for this crime upon individuals, not upon States." 259 Senator Edmunds agreed, maintaining that "under the thirteenth amendment there is no question but that Congress may take all necessary means to prevent the reestablishment of slavery." 260

Shellaburger also argued that the Act fell within Congress's power to enforce the privileges or immunities of citizenship under Section 5 of the Fourteenth Amendment, because Congress had the power to protect the exercise of citizenship rights when the states were failing to protect them. ${ }^{261}$ Representative Hoar agreed, echoing Shellaburger's theory of equal protection and pointing out that the Klu Klux Klan was terrorizing people because of their loyalty to the United States. ${ }^{262}$ These members of Congress rejected the argument that the Fourteenth Amendment only reached state action, pointing out that the Amendment also guarantees the equal protection of the laws. ${ }^{263}$ Members of Congress who voted in favor of the Act presumably relied on both Amendments to justify their regulation of private criminal activity. ${ }^{264}$

Sadly, the Enforcement Act was not enforced by the federal government for almost a century, as Jim Crow took hold of the southern states. ${ }^{265}$ During the Second Reconstruction of the 1960s, however, the Justice Department relied on the statute to protect civil rights workers and the Court upheld it. In what

256 See Cong. Globe, 42d Cong., Spec. Sess. 81, 85-86 (statement of Rep. Bingham).

257 Id. at 85.

${ }^{258} I d$.

259 Id.

${ }^{260}$ Cong. Globe, 42d Cong., 1st Sess. 686, 695 (1871) (statement of Sen. Edmunds).

261 Cong. Globe, 42d Cong., Spec. Sess. 67, 69 (statement of Rep. Shellabarger). Although the Supreme Court seemed to adopt this view in United States v. Guest, 383 U.S. 745, 783 (1966) (Brennan, J., concurring in part and dissenting in part), it resoundingly rejected it in United States v. Morrison, 529 U.S. 598, 624 (2000).

262 See Cong. Globe, 42d Cong., 1st Sess. 329, 332-34 (statement of Rep. Hoar).

263 See id. For an excellent explanation of this theory of equal protection, see JUDITH A. Baer, Equality Under the Constitution: Reclaiming the Fourteenth Amendment 102-03 (1983).

${ }^{264}$ In Guest, the Supreme Court upheld the Act as an exercise of the Section 2 power, finding that theory to be more persuasive and sidestepping the controversial issue of whether the Fourteenth Amendment could be enforced against private parties. Guest, 383 U.S. at 760. Thus, the Court agreed with the members of this late session of the Reconstruction Congress that the Section 2 power was both flexible and broad.

265 See GolubofF, supra note 6, at 7. 
was arguably the apex of the Warren Court's deference to Congress, Griffin v. Breckenridge, a unanimous Court upheld a cause of action under 42 U.S.C. $\S$ 1985(3) brought by a group of African American men against private citizens who had beaten them based on the mistaken belief that they were civil rights workers. ${ }^{266}$ The indictment alleged that defendants had conspired to deprive the victims of

their rights to freedom of speech, movement, association and assembly; their right to petition their government for redress of their grievances; their rights to be secure in their persons and their homes; and their rights not to be enslaved or deprived of life and liberty other than by due process of law. ${ }^{267}$

The Court held that $\S 1985(3)$ was a valid exercise of the Section 2 power because "the varieties of private conduct that [Congress] may make criminally punishable or civilly remediable extend far beyond the actual imposition of slavery or involuntary servitude. By the Thirteenth Amendment, we committed ourselves as a Nation to the proposition that the former slaves and their descendants should be forever free."268 Thus, in Griffin, the Court held that the Thirteenth Amendment authorized Congress to protect virtually all civil rights from violation by private actors, as long as those actors were motivated by "some racial, or perhaps otherwise class-based, invidiously discriminatory animus." 269 The Court's ruling was consistent with the intent of the Framers of the Thirteenth Amendment, who believed that the Amendment empowered them to protect fundamental rights.

Analyzing the Reconstruction Era civil rights legislation debates should also put to rest the question of whether Congress's Section 2 power is limited to remedying discrimination based on race. Some scholars have argued that the best use of the enforcement power is to remedy race-based discrimination. ${ }^{270}$ Others claim that the power is not so limited. ${ }^{271}$ When the Court has considered Congress's use of Section 2 to remedy race discrimination, it has defined the meaning of "race" broadly, consistent with the understanding of racial classifications at the time of Reconstruction. Neither Congress nor the

266 Griffin v. Breckenridge, 403 U.S. 88, 89-92, 105 (1971). Justice Harlan, in his concurring opinion, agreed with the Court's interpretation of the Section 2 power. Id. at 107 (Harlan, J., concurring).

${ }^{267} I d$. at 90.

268 Id. at 105.

${ }^{269} I d$. at 102.

${ }^{270}$ See Carter, supra note 27, at 1318 (“[A]s the group's link to slavery grows more attenuated, the nature of the injury must be more strongly connected to the system of slavery to be rationally considered a badge or incident thereof.").

271 See Tsesis, supra note 27, at 1836 ("Thirteenth Amendment-based statutes may likewise respond to discrimination, but they may also interpret the meaning of 'liberty' in the Constitution and act upon it."). 
Court has ever considered Section 2 to be limited only to discrimination against African Americans.

While it is clear that the principal concern of the Reconstruction Era Congress was to protect the rights of the newly freed slaves and their northern sympathizers, members of the Reconstruction Congress did not intend the protections of the Thirteenth Amendment to be limited to newly freed slaves. Rather, they intended to protect all races from invidious discrimination. This is evidenced by the language of both the Civil Rights Act of 1866, which granted "any person" the same rights as a white citizen, ${ }^{272}$ and the 1871 Enforcement Act, which protected "any person or class of persons" from conspiracies to deprive them of their civil rights. ${ }^{273}$ Reconstruction Era statutes based on Section 2 prohibited peonage regardless of its source, expressly prohibiting Native Americans treating other Native Americans as peons and addressing the peonage-like exploitation of young Italian immigrants in urban areas. ${ }^{274}$ It is therefore apparent that the Framers of the Thirteenth Amendment viewed it as a broad font of liberty-based rights not just for slaves, but for every person within its jurisdiction.

The Supreme Court has never imposed a racial limitation on Section 2 based legislation. As the Court pointed out in Hodges v. United States, the Thirteenth Amendment

reaches every race and individual, and if in any respect it commits one race to the Nation it commits every race and every individual thereof.

Slavery or involuntary servitude of the Chinese, of the Italian, of the Anglo-Saxon are as much within its compass as slavery or involuntary servitude of the African. ${ }^{275}$

In Griffin v. Breckenridge, the Court interpreted $\S 1985$ to apply only to conspiracies based on "racial, or perhaps otherwise class-based, invidiously discriminatory animus." 276 This ruling, however, does not limit Congress from enacting new legislation prohibiting other types of discrimination. Moreover, the Court has interpreted the meaning of race broadly, encompassing any group of people that was considered to be a different race from the Caucasian race by the Framers of the Thirteenth Amendment. ${ }^{277}$

The Court has agreed with Congress that Section 2 is a potent weapon to address race-based animus. In Saint Francis College v. Al-Khazraji, the Court held that a person of Arabic descent could bring a discrimination claim under $\S$

${ }^{272}$ Civil Rights Act of 1866, ch. 31, 14 Stat. 27, 27 (codified as amended at 42 U.S.C. $\S \S$ 1981-1983 (2006)).

2731871 Enforcement Act, 17 Stat. 13, 13 (codified as amended in scattered sections of 18 U.S.C. and 42 U.S.C.).

274 See infra notes 294-304 and accompanying text.

275 Hodges v. United States, 203 U.S. 1,17 (1906).

276 Griffin v. Breckenridge, 403 U.S. 88, 102 (1971).

277 See, e.g., Shaare Tefila Congregation v. Cobb, 481 U.S. 615, 616-18 (1987); Saint Francis Coll. v. Al-Khazraji, 481 U.S. 604, 613 (1987). 
1981.278 The Court stated that at the time of Reconstruction, racial classifications commonly used in the twentieth century were divided into a number of subsidiary classifications, and that the legislative history of the Thirteenth Amendment is filled with references to a variety of races, including Scandinavian, Chinese, Latin, Spanish, Anglo-Saxon, Jewish, Mexican, Mongolian, Gypsy, and German. ${ }^{279}$ Thus, "[p]lainly all those who might be deemed Caucasian today were not thought to be of the same race at the time $\S$ 1981 became law." 280

In another case, the Court held that Jewish plaintiffs whose synagogue had been sprayed with anti-Semitic slogans could raise claims under $\S \S 1981$, 1982, and 1985(3).281 Noting that "the question before us is not whether Jews are considered to be a separate race by today's standards, but whether, at the time $\S 1982$ was adopted, Jews constituted a group of people that Congress intended to protect," the Court concluded, "Jews and Arabs were among the peoples considered to be distinct races and hence within the protection of the statute." 282 Therefore, while the Section 2 power is not limited to remedying race discrimination, it seems clear that Congress could use its Section 2 power to remedy a broad range of racial subordination.

\section{B. Protecting the Rights of Workers with the Anti-Peonage Acts}

Members of the Reconstruction Congress made it clear that they intended not only to ban slavery, but also slavery-like employment practices. This is evident from the face of the Thirteenth Amendment, which bans both slavery and involuntary servitude. ${ }^{283}$ The Reconstruction Congress enacted several statutes banning the practice of peonage, a system by which debtors are bound in servitude to their creditors until their debts are paid. It also had to consider when imprisonment conditions of duly convicted criminals rose to the level of prohibited "involuntary servitude." These debates reveal a broad view of Congress's power to address labor relations pursuant to Section 2. The Reconstruction Congress used its power to end employment practices that subordinated workers without the use of brute force that characterized chattel slavery. Moreover, these measures were not limited to racial minorities, but were intended to improve the status of all workers regardless of race.

On March 2, 1867, Congress enacted the first Anti-Peonage Act. ${ }^{284}$ The Act prohibited "the holding of any person to service or labor under the system known as peonage" in any place in the United States or the territory of New

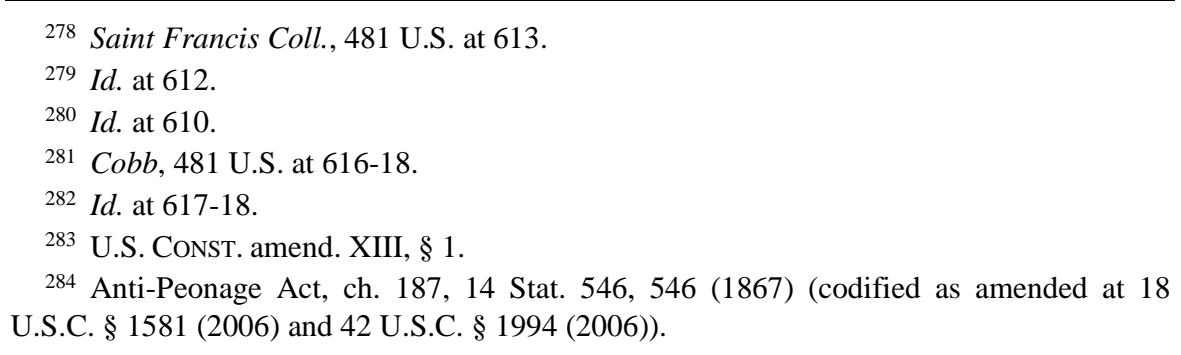


Mexico.285 Peonage was defined as "establish[ing], maintain[ing], or enforc[ing], directly or indirectly, the voluntary or involuntary service or labor of any persons as peons, in liquidation of any debt or obligation, or otherwise."286 The Act also prohibited arresting or returning any person to the condition of peonage. ${ }^{287}$ In the Senate, opponents argued that peonage was voluntary if the peon voluntarily entered into the relationship with his creditor. ${ }^{288}$ Supporters of the Act claimed that it did not matter whether labor chose servitude - what mattered was "whether the resulting condition was degrading to workers and employers." 289 For example, Senator Buckalew explained that the terms of debt service were "always exceedingly unfavorable to [the laborer]," and the system "degrade[d] both the owner of the labor and the laborer himself." 290 The sponsor of the bill, former Free Soiler Senator Henry Wilson, explained that the bill would elevate the status of all low wage workers because in areas where peonage had been eliminated, such as New Mexico, "peons who once worked for two or three dollars a month are now able to command respectable wages." 291 In the House, there was little debate over the Anti-Peonage Act. ${ }^{292}$ Representative Kasson explained that he believed that peonage was "very much like slavery," 293 and his colleagues evidently agreed.

The Reconstruction Congress also enacted two little known anti-peonage measures. The first, the 1874 Padrone Act, prohibited the practice of bringing children from Italy to large cities, isolating them, and exploiting their labor. ${ }^{294}$ This Act extended its protections far beyond African American freed slaves. The second provision was a joint resolution conveying authority upon the United States military to "reclaim from peonage" women and children being held in that condition "in the territory adjacent to their homes" and on the Navajo reservation. ${ }^{295}$ These measures reflect the Reconstruction Congress's

\section{Id.}

286 Id.

287 Id.

288 See Cong. Globe, 39th Cong., 2d Sess. 1571, 1571 (1867) (statement of Sen. Davis) ("I think this feature of a man's working to pay the debts the he owes to his creditors, in a modified form at least, ought to exist.").

289 James Gray Pope, Contract, Race and Freedom of Labor in the Constitutional Law of “Involuntary Servitude," 119 YALE L.J. (forthcoming 2010) (manuscript at 14, on file with author).

290 Cong. Globe, 39th Cong., 2d Sess. 1571, 1572 (statement of Sen. Buckalew).

291 Id. at 1571 (statement of Sen. Wilson).

292 Cong. Globe, 39th Cong., 2d Sess. 344.

293 Id. at 346 (statement of Rep. Kasson).

294 An Act to Protect Persons of Foreign Birth Against Forcible Constraint or Involuntary Servitude, ch. 464, 18 Stat. 251 (1874) (codified as amended at 18 U.S.C. § 1584 (2006)).

295 Joint Resolution to Aid in Relieving from Peonage Women and Children of the Navajo Indians, H.R. Con. Res. 83, 40th Cong. (1868). 
desire to end exploitative labor practices regardless of whether they were based on racial supremacy or had any connection to the chattel slavery of African Americans.

In early 1867, Congress considered whether the practice of selling prisoners into slavery violated the Thirteenth Amendment. ${ }^{296}$ Some state courts had approved this practice, including courts in Maryland. ${ }^{297}$ Representative Kasson spoke in favor of a joint resolution declaring this practice "involuntary servitude" prohibited by the Thirteenth Amendment, notwithstanding the courts' approval. ${ }^{298}$ Kasson asserted his authority to interpret the Amendment, arguing that Section 2 gave Congress the power "to define the species of slavery or involuntary servitude into which a free man may be lawfully condemned by the laws of the country." 299 He argued that Congress's construction not only has a legal force, but "a vast moral force throughout the United States." ${ }^{300}$ Agreeing with Kasson, Representative Thayer proposed an amendment that would make it a crime to sell or attempt to sell any person. ${ }^{301}$ He commented, "I do not like, I must confess, the idea of laws being passed purporting upon their face to construe the Constitution. But I assume and I presume no man doubts that the true interpretation of the constitutional amendment is exactly that which is proposed by the gentleman from Iowa." 302 The bill was approved in the House by a vote of 121 to 25, with 45 abstentions. ${ }^{303}$ With this vote, members of the Reconstruction Congress made it clear that they did not want the nation's penal system to become a proxy for slavery. ${ }^{304}$

In Clyatt v. United States, the Court upheld the Anti-Peonage Act as an exercise of Congress's power to enforce the Thirteenth Amendment. ${ }^{305}$ Two years later, in Bailey v. Alabama, the Court indicated that it was open to the argument that an employer's use of coercion against an employee could turn

296 Cong. Globe, 39th Cong., 2d Sess. 344, 344-48.

297 Id. at 344-45.

${ }^{298} I d$. (advising that the practice should be prohibited, and emphasizing that Congress has the right, under the Thirteenth Amendment, "to say what falls within the terms of that amendment as being slavery or involuntary servitude").

${ }^{299} I d$. at 345.

$300 \mathrm{Id}$.

301 Id. at 346.

$302 I d$.

303 Id. at 348 .

${ }^{304}$ Unfortunately, following the Reconstruction Era, the use of forced labor on prison camps in the South became widespread, leading to a system very much like slavery. See generally Douglas A. Blackmon, Slavery by AnOther NAme: The Re-Enslavement of Black People in America from the Civil War to World War II (2008).

305 Clyatt v. United States, 197 U.S. 207, 218 (1905) ("It is not open to doubt that Congress may enforce the Thirteenth Amendment by direct legislation, punishing the holding of a person in slavery or in involuntary servitude except as a punishment for crime."). 
what was initially a voluntary relationship into an involuntary one. ${ }^{306}$ In the 1944 case of Pollock v. Williams, the Court set the standard for determining when an employment relationship is involuntary as it struck down a Florida statute that made it a misdemeanor to leave an employer after promising to work for the employer and receiving compensation for the promised work. ${ }^{307}$ The Court held that the statute violated the Thirteenth Amendment because it forced the employee to remain in a relationship of involuntary servitude to the employer. ${ }^{308}$ Justice Jackson, writing for the majority, explained that employment relationships are generally presumed voluntary because "the defense against oppressive hours, working conditions, or treatment is the right to change employers." 309 However, "[w]hen the master can compel and the laborer cannot escape the obligation to go on, there is no power below to redress and no incentive above to relieve a harsh overlordship or unwholesome conditions of work." ${ }^{10}$ Thus, the Court held that when an employment practice gave undue power to the employer over the employee, it violated the Thirteenth Amendment prohibition against involuntary servitude. ${ }^{311}$ The Pollock Court therefore articulated the anti-subordination promise of the Thirteenth Amendment.

More recently, in United States v. Kozminski, the Court held that an employment relationship was not unduly coercive, and thus involuntary, when employers used only psychological coercion to keep their employees in exploitative conditions. ${ }^{312}$ The Court ruled that both statutes were limited to remedying "cases involving the compulsion of services by the use or threatened use of physical or legal coercion."313 In 2000, Congress responded by enacting the Trafficking Victims Protection Act ("TVPA"), which prohibits the trafficking of persons for sex or other labor or services. ${ }^{314}$ With the TVPA,

306 Bailey v. Alabama, 211 U.S. 452, 454 (1908) (avoiding the question of whether a law which makes an employee's refusal to perform an employment contract prima facie evidence of intent to commit larceny against the employer establishes a system of peonage in violation of the Constitution and laws of the United States, but noting that it was possible that "in view of its operation and intent the whole statute ought to be held void").

307 Pollock v. Williams, 322 U.S. 4, 5, 25 (1943).

308 Id. at 25.

309 Id. at 18 .

$310 I d$.

311 See id. at 18, 25.

312 United States v. Kozminski, 487 U.S. 931, 950 (1988).

313 Id. at 948.

314 Trafficking Victims Protection Act of 2000, Pub. L. No. 106-386, 114 Stat. 1464, 1490 (codified as amended at 22 U.S.C. $\$ \$ 7101-7112$ (2006)). For an excellent discussion of the TVPA and the problem of human trafficking, see generally Kathleen Kim, Psychological Coercion in the Context of Modern-Day Involuntary Labor: Revisiting United States v. Kozminski and Understanding Human Trafficking, 38 U. TOL. L. REV. 941 (2007) (discussing how current anti-trafficking laws such as the TVPA leave their scope ambiguous, and thereby difficult to enforce, by failing to define psychological coercion). 
Congress overruled the Court's interpretation of the Anti-Peonage Act by providing that "[i]nvoluntary servitude statutes are intended to reach cases in which persons are held in a condition of servitude through nonviolent coercion." ${ }^{315}$ The TVPA is discussed more fully in Part V of this Article.

\section{ENFORCING THE AMENDMENT - THE NEW DEAL}

The Section 2 power lay dormant through the first half of the twentieth century, consistent with the country's dominant attitude towards racial equality in the aftermath of Reconstruction. The system of Jim Crow solidified in the South, and racial segregation became the norm in the North. ${ }^{316}$ Congress repealed a number of Reconstruction-based statutes, and the executive branch was reluctant to enforce the statutes that remained. ${ }^{317}$ Even as the Thirteenth Amendment's promise of racial justice was at its ebb, the nascent United States labor movement relied upon its promise of economic freedom.

Leaders of the early labor movement nourished the free labor tradition of Reconstruction and claimed that the Thirteenth Amendment protected fundamental rights of all workers, including the right to organize and strike. ${ }^{318}$ The courts rejected this vision, instead adopting an individualistic view of the right to contract in cases such as Lochner v. New York. ${ }^{319}$ Labor's view of the Thirteenth Amendment, however, had a strong influence on the political process, as evidenced by Congress's creation of a statutory right to organize and bargain collectively in the Wagner Act. ${ }^{320}$ Although supporters of the Wagner Act did not base the Act on Section 2, they made it clear that they believed the worker's right to organize and strike was a liberty interest protected by the Constitution and necessary to remedy employers' subordination of their workers. $^{321}$ For political reasons, however, that

31522 U.S.C. $\$ 7101(\mathrm{~b})(13)$ (emphasis added).

316 See FONER, supra note 209, at 587.

317 Id.; see also CARR, supra note 70, at 24.

318 See James Gray Pope, Labor's Constitution of Freedom, 106 YALE L.J. 941, 942, 943, 959 (1997).

319 See Lochner v. New York, 198 U.S. 45, 64 (1905) (holding that a New York labor law restricting the number of hours that bakers could work unreasonably and unnecessarily interfered with the right and liberty of the individual to contract). See generally WiLliam E. Forbath, LAW AND the SHAPING OF THE AMERICAN LABOR Movement (1991) (providing an overview of courts' invalidation of labor laws for the sake of "liberty of contract" and "property rights").

320 See National Labor Relations Act, ch. 372, 49 Stat. 449, 449 (1935) (codifed as amended at 29 U.S.C. $§ \S 151-169$ (2006)); ZIETLOW, ENFORCING EQUALITY, supra note 15, at 76-77 (describing how the debates over the Wagner Act revealed that many members of Congress viewed the right to organize as "a fundamental human right that would facilitate workers' belonging to society as equal citizens").

321 ZIETLOW, ENFORCING EQUALITY, supra note 15, at 76. 
Congress avoided confronting the brutal racial subordination of the Jim Crow South. 322

Labor's theory of economic rights also heavily influenced some of the first legal attempts to articulate a twentieth century theory of civil rights - the Civil Rights Section ("CRS") of the Department of Justice. ${ }^{323}$ The CRS lawyers added the element of racial justice to their philosophy of individual rights by adopting an anti-subordination theory of civil rights that incorporated both racial and economic equality - a theory reflecting that of the Framers of the Thirteenth Amendment. ${ }^{324}$ Congress responded to the CRS by amending the Anti-Peonage Act in 1948 to make it easier to prosecute the economic exploitation of blacks in the Jim Crow South. ${ }^{325}$

The 1948 amendment to the Anti-Peonage Act enabled CRS lawyers to launch "a broader attack on the southern political economy that made [the employer-employee] relationship[] possible[,] ... [shifting their] focus from a given laborer to the southern labor market itself - to the structural, legal obstacles to labor mobility in the South." 326 Their goal was to fill in the gaps left by New Deal protections for workers and complete the anti-subordination vision of the Reconstruction Congress. ${ }^{327}$ The CRS lawyers sought to establish a right to workers' mobility. ${ }^{328}$ They challenged debt peonage statutes and other state laws that made it difficult for agricultural and domestic workers to leave their employers, in order to ensure a system of free and voluntary labor for blacks throughout the country. ${ }^{329}$ In the 1948 Amendment, the use of the phrase "involuntary servitude" in the place of slavery left space for the CRS lawyers to broaden the meaning of involuntariness to protect the most disempowered workers in the country. ${ }^{330}$ It also facilitated the CRS's successful attacks on the "shocking conditions" that some workers were forced to endure as CRS convinced courts that those conditions violated the Thirteenth Amendment and the Anti-Peonage Act. ${ }^{331}$ Thus, the 1948 Amendment to the Anti-Peonage Act facilitated the broadest antisubordination based legal campaign to improve the conditions of disempowered workers in the history of America.

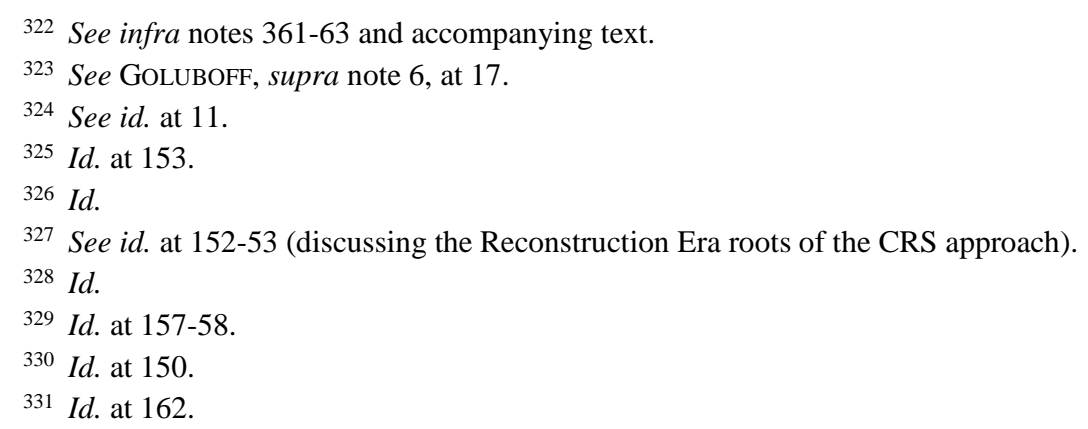




\section{A. The Wagner Act}

In the earlier part of the twentieth century, leaders of the labor movement such as Samuel Gompers of the American Federation of Labor and Andrew Furuseth of the Seaman's Union, seized on the free soil philosophy of the abolitionist Framers of the Thirteenth Amendment. ${ }^{332}$ They argued that the Amendment protected the right to join a union because working without the right to organize, bargain collectively, or strike was tantamount to slavery. ${ }^{333}$ No court ever agreed with this message of popular constitutionalism, but some members of Congress accepted it. In 1915, Congress enacted the La Follete Seaman's Act of 1915, which gave sailors the right to quit their jobs. ${ }^{334}$ Furuseth fiercely advocated for the Act, arguing that the Thirteenth Amendment established the right to quit. ${ }^{335}$ Although he did not rely on Section 2 as the basis for the statute, the Act's chief sponsor, Senator Robert La Follette, proclaimed that he believed that the Thirteenth Amendment had become "a covenant of refuge for the seamen of the world." 336 Members of Congress also evoked labor's theory of the Thirteenth Amendment during the debates over the Wagner Act in 1934 and 1935. Supporters of the Wagner Act evoked imagery of slavery and freedom, and explained that the rights to organize and to strike were necessary to protect the workers' freedom to contract.

For example, the Act's sponsor, Senator Robert Wagner, argued that the equality of bargaining power protected by the right to organize was a fundamental right. ${ }^{337}$ In a 1934 speech, Wagner explained that "the right to bargain collectively, guaranteed to labor by Section 7(a) of the Recovery Act, is a veritable charter of freedom of contract; without it there would be slavery by contract." 338 Wagner's ally, Representative Carpenter of Nebraska elaborated: "The worker's right to form labor unions and to bargain collectively is as much his right as his right to participate through delegated representatives in the making of laws which regulate his civic conduct. Both are inherent rights." 339 Senator Walsh agreed that "any injunction or any law that prevents a man from striking . . . is a law of servitude, and that is the

332 See Pope, supra note 318, at 964-66.

333 See id.

${ }^{334}$ La Follette Seamen's Act of 1915, 63 Pub. L. No. 302, 38 Stat. 1164.

335 James Gray Pope, The Thirteenth Amendment Versus the Commerce Clause: Labor and the Shaping of American Constitutional Law, 1921-1957, 102 Colum. L. REv. 1, 31 (2002).

336 Senator La Follette, Telegram to the Sailor's Union (Mar. 6, 1915), quoted in HYMAN Weintraub, ANDrew Furuseth: Emancipator of the SeAmen 132 (1959).

337 See 78 Cong. REC. 3678, 3678-79 (1934) (statement of Sen. Wagner).

338 Id. at 3679.

339 Id. at 9060, 9061 (statement of Sen. Carpenter). 
principle we have to keep in mind. It is the difference between freedom and servitude." 340

Supporters of the Wagner Act evoked the Reconstruction Era to argue in favor of the Act. For example, Representative William P. Connery, Jr., exclaimed,

The Civil War was fought over the question of whether man should be free or be enslaved. ... Today, despite the fact that all our people are free in that they have the right to work and live where they please ... there are many who contend that our toilers live in virtual economic slavery in that they are denied an income which will provide a decent standard of living for themselves and their families and too often they are denied the right of collective bargaining. ${ }^{341}$

Representative Vito Marcantonio agreed, "Unless Congress protects the workers what liberty have they? Liberty to be enslaved, liberty to be crucified under the spread-out system, liberty to be worked to death under the speed-up system, the liberty to work at charity wages, the liberty to work long hours." 342 His colleague, Representative Wood, said simply: "[This bill] involves an ageold principle - the desire for freedom." ${ }^{343}$ Representative Truax of Ohio called the bill "an emancipation for American labor." 344

The Wagner Act defined the right to organize as a fundamental right. ${ }^{345}$ Nonetheless, members of Congress based their enforcement power not in the Thirteenth Amendment, but in their power to regulate interstate commerce. ${ }^{346}$ This decision was, in part, a strategic one. At a time when Congress and the President were often at odds with the Court over New Deal measures, Wagner and his allies believed that the best way to convince the Court to uphold the Act was to justify it as preventing strikes, which were barriers to the flow of interstate commerce. ${ }^{347}$ Wagner and his staff were also wary of using openended language, which would subject the Act to narrow interpretations by hostile courts. ${ }^{348}$ Some members of Wagner's staff doubted labor's reliance on the Thirteenth Amendment and simply preferred to rely on the more

34078 Cong. ReC. 12,024, 12,034 (statement of Sen. Walsh).

34179 CONG. ReC. 8356, 8537 (1935) (statement of Rep. Connery).

34279 CONG. REC. 9676, 9700 (statement of Rep. Marcantonio).

343 Id. at 9709 (statement of Rep. Wood).

${ }^{344} I d$. at 9714 (statement of Rep. Traux).

345 See National Labor Relations Act, 29 U.S.C. $\$$ 151-169 (2006).

346 National Labor Relations Act, ch. 372, 49 Stat. 449, 449 (1935); see also Pope, supra note 335 , at $51-53$.

347 See ZieTlow, EnForcing EQuAlity, supra note 15, at 79-80.

${ }^{348}$ Id. at 80; see also William E. Forbath, The New Deal Constitution in Exile, 51 DukE L.J. 165, 175 (2001) (discussing the New Dealers' constitutional theory and their concern over allowing the Courts to define labor rights). 
conventional language of interstate commerce. ${ }^{349}$ However, the Act's supporters believed that it protected not just economic rights, but fundamental human rights. ${ }^{350}$ Years later, Wagner's legislative aide, Kenneth Keyserling, recalled that Wagner believed the Act was needed because "the working person's freedom could only be secure when economic health had been assured." 351 According to Keyserling, Wagner believed that the primary purpose of the Act was "to make the worker a free man."352 Wagner and the Act's other supporters understood the connection between freedom and economic empowerment. They believed that both were necessary to combat the subordination of workers by their employers. ${ }^{353}$

As Wagner had anticipated, the Supreme Court seized on the conservative narrative when it upheld the constitutionality of the Wagner Act in NLRB $v$. Jones. ${ }^{354}$ The Court held that the Act was justified as a measure to reduce the strikes that burdened interstate commerce. ${ }^{355}$ Since then, the courts have come to consider the right to organize as merely an economic right. ${ }^{356}$ The Court has construed the statute narrowly, substantially reducing its liberating potential. ${ }^{357}$ After Congress enacted the Wagner Act, union membership increased substantially, as did the general standard of living for American workers. ${ }^{358}$ This phenomenon reflected the wisdom of the Free Soilers in the Reconstruction Congress, who believed that improving the status of workers on the bottom would help all workers. ${ }^{359}$ Since the rise of industrialism and trade unionism occurred after the Civil War, there is little evidence that Republicans supported unionization or the right to strike. ${ }^{360}$ However, as

349 ZiETLOw, ENFORCING EQUALITY, supra note 15, at 80; see also Pope, supra note 335, at 51-53.

350 ZIETLOW, ENFORCING EQUALITY, supra note 15, at 76-79.

${ }^{351}$ Kenneth M. Casebeer, Holder of the Pen: An Interview with Leon Keyserling on Drafting the Wagner Act, 42 U. MiAMI L. REV. 285, 295-96 (1987).

352 Id. at 329.

353 See id. at 295-96.

354 NLRB v. Jones \& Laughlin Steel Corp., 301 U.S. 1, 30-32, 49 (1937).

355 Id. at 31-33.

356 See James Gray Pope, How American Workers Lost the Right to Strike, and Other Tales, 103 Mich. L. REv. 518, 524 (2004) (discussing how the economic justification for the Act began to overtake the human rights explanation).

357 See id.

358 See U.S. DeP'T of LABOR, Report on the AMERICAN Workforce 69 (2001) (reporting that union membership rose from fourteen to twenty-eight percent); LEO TROY, Trade Union Membership, 1897-1962, at 1-2 (1965) (providing more detailed figures relating to union membership).

359 See supra note 148 and accompanying text.

360 See FonER, supra note 72, at 26-27. Some Reconstruction Era Republicans may have actually been against unionization. See, e.g., Heather Cox Richardson, The Death of RECONSTRUCTION 102 (2001) (arguing that Republican fears of labor movements and fears 
members of the New Deal Congress recognized, the Wagner Act still serves as a good example of the economic anti-subordination ideology of the Thirteenth Amendment. Unfortunately, Congress excluded agricultural and domestic workers - who were predominantly African American - from the protections of the Wagner Act and other statutes that they enacted to protect workers. ${ }^{361}$ Wagner and his allies deliberately omitted those workers from the Act in order to win the support of segregationist Democrats in Congress. ${ }^{362}$ This tragic yet necessary compromise limited the anti-subordinating effect of the Wagner Act for workers of color. ${ }^{363}$

\section{B. The 1948 Anti-Peonage Act}

In 1939, Attorney General Frank Murphy, as part of the Roosevelt administration, furthered the revival of the Thirteenth Amendment by creating the first Civil Rights Section of the Department of Justice. ${ }^{364}$ CRS attorneys focused primarily on enforcing the Thirteenth Amendment and Thirteenth Amendment-based statutes, including the anti-peonage statutes and what remained of the Reconstruction Era Enforcement Acts. ${ }^{365}$ The CRS brought prosecutions for police brutality under the provision now codified as 18 U.S.C. $\S 242.366$ They also brought a number of prosecutions under the anti-peonage statute, attempting to expand the New Deal protections for workers to the southern African American agricultural workers who had been excluded from many of the statutory protections. ${ }^{367}$ Hence, the CRS attorneys "made the

of African-American radicalization distracted from enforcement of Reconstruction and contributed to its ultimate downfall).

361 See ZiETlow, Enforcing EQuAlity, supra note 15, at 94 (discussing Congress's failure to address racial justice issues while debating the Wagner Act). Those workers were also excluded from the Fair Labor Standards Act, which established minimum wages and maximum hours for workers. See Fair Labors Standards Act, Pub. L. No. 75-718, 52 Stat. 1060 (codified as amended at 29 U.S.C. $\$ \S 201-219$ (2006)).

362 See ZieTlow, Enforcing Equality, supra note 15, at 94 (discussing Wagner's submission to the American Federation of Labor, conservative Republicans, southern Democrats, and business groups to remove anti-discrimination language from the Act).

363 Notwithstanding this omission, workers of color in other industries benefitted from the Wagner Act, and the northern civil rights movement had its roots in the union movement. See Martha Biondi, To Stand and Fight: The Struggle For Civil Rights IN Postwar New York City 17 (2003) (explaining the connection between the labor movement and the civil rights movement); ZIETLOW, ENFORCING EQUALITY, supra note 15, at 95-96.

364 See CARR, supra note 70, at 1.

$365 I d$. at 56-57, 77 (outlining the three main statutes which the CRS sought to enforce); GolubofF, supra note 6, at 11 (contrasting the CRS's focus on the Thirteenth Amendment statutes with the NAACP lawyers' focus on destroying Jim Crow).

366 See CARR, supra note 70, at 151-63.

367 GolubofF, supra note 6, at 11. 
Thirteenth Amendment's prohibition on involuntary servitude central to their practice." 368

The first CRS attorneys recognized the connection between racial and economic subordination, especially in the Jim Crow South. ${ }^{369}$ They engaged in a litigation strategy that started from the standpoint of economic rights and moved towards advocating racial justice. To accomplish these goals, they relied not on the Fourteenth Amendment, but on the Thirteenth Amendment, because it "offered the government lawyers the chance to work out the integration of the rights they had inherited and the rights they hoped to vindicate." 370 Thus, they relied on an anti-subordination theory of equality, and called on members of Congress to amend and modernize the Anti-Peonage Act. 371

In 1948, Congress responded to CRS requests and amended the AntiPeonage Act to make it easier for CRS attorneys to win prosecutions under the Act. ${ }^{372}$ The amendment replaced the phrase "slave trade" with the broader and more contemporary sounding phrase "involuntary servitude," and the new provision made it a crime to hold someone in a condition of involuntary servitude regardless of the existence of any debt. ${ }^{373}$ There was no congressional debate about the provision, but there is evidence that " $[t]$ he [CRS] lawyers thought these revisions would ideally enable prosecutors to use a single statute to attack non-debt-based involuntary servitude" by clarifying that it applied to present day conditions of debt peonage. ${ }^{374}$ Shortly thereafter, the Court ruled in Pollock v. Williams that the amendment was intended to incorporate a generous interpretation of involuntariness. ${ }^{375}$ Until then, CRS lawyers had often been stymied by the need to rely on more general Reconstruction Era civil rights statutes to attempt to redefine the meaning of the Thirteenth Amendment itself. ${ }^{376}$ They wanted to make it clear that the Thirteenth Amendment serves "as a basis for a positive, comprehensive federal program - a program defining fundamental civil rights protected by federal machinery against both state and private encroachment." 377 Their allies in Congress evidently agreed.

368 Id.

369 See id. at 80.

${ }^{370}$ Id. at 114. See generally CARR, supra note 70 (describing the CRS litigation campaign).

371 See GolubofF, supra note 6, at 150.

372 See id.

373 See Anti-Peonage Act, 62 Stat. 772, 772 (codified as amended at 18 U.S.C. $§ 1581$

(2006) and 42 U.S.C. $§ 1994$ (2006)); GolubOFF, supra note 6, at 150.

374 See Goluboff, supra note 6, at 150.

375 See CARR, supra note 70, at 3 (citing Pollock v. Williams, 322 U.S. 4 (1944)).

376 See Goluboff, supra note 6, at 150; Henry Putzel Jr., Federal Civil Rights Enforcement: A Current Appraisal, 99 U. PA. L. REV. 439, 445 (1951).

377 CARR, supra note 70, at 36. 


\section{ENFORCING THE AMENDMENT - THE SECOND RECONSTRUCTION AND BEYOND}

The 1948 Democratic Party platform and the anti-peonage statute signaled a renewed interest in civil rights legislation among some members of Congress. From 1937 to 1950, a flood of civil rights legislation was introduced in Congress. ${ }^{378}$ Segregationists in Congress blocked or watered down that legislation until 1964, when Congress enacted the first major civil rights legislation enacted since Reconstruction. The 1964 Civil Rights Act contained provisions prohibiting race discrimination in places of public accommodation, in employment, and by recipients of federal funds. ${ }^{379}$ Even though the Act addressed the economic impact of race discrimination, members of Congress did not consider basing the Act on the Thirteenth Amendment. Instead, they relied on the Commerce Clause and Section 5 of the Fourteenth Amendment. ${ }^{380}$ By then, the Equal Protection Clause had replaced the Thirteenth Amendment in the imagination of civil rights advocates. ${ }^{381}$ The 1964 Act provided a crucial precedent for other civil rights measures, including the 1968 Fair Housing Act, which enabled Congress to enforce other Reconstruction Amendments. ${ }^{382}$

At the turn of the millennium, lawmakers turned their vision outward to address the international trafficking of workers with the Trafficking Victims Protection Act of 2000 ("TVPA"). 383 Members of Congress debating the TVPA indicated a broad understanding of the "involuntary" work practices outlawed by the Thirteenth Amendment. ${ }^{384}$ In this first twenty-first century statute protecting rights of belonging, members of Congress adopted a comprehensive approach to the combined effect of economic, racial, and gender subordination that characterizes the international trafficking of workers. Enacted with virtually unanimous approval, ${ }^{385}$ the TVPA thus reflects the Reconstruction Era anti-subordination philosophy and provides an excellent template for such measures in the future.

378 BIONDI, supra note 363, at 54.

379 See Civil Rights Act of 1964, Pub. L. No. 88-352, 78 Stat. 241 (codified as amended at 42 U.S.C. $\$ \S 2000(a)-(h)(2006))$. See generally Zietlow, To Secure, supra note 53 (contrasting the 1964 Act with Brown v. Board of Education of Topeka, 347 U.S. 483 (1954)).

380 Zietlow, To Secure, supra note 53, at 977-78.

381 See GolubofF, supra note 6, at 4.

382 See infra Part V.A.

383 Trafficking Victims Protection Act of 2000, Pub. L. No. 106-386, 114 Stat. 1464 (codified as amended at 22 U.S.C. $\S \S 7101-7112$ (2006)).

384 See infra Part V.B.

385 The Bill passed the House after a suspension of the Rules, CONG. REC. H. 2687 (May 9, 2000), and the Senate on a voice vote, ConG. REC. S. 7781 (July 27, 2000). 


\section{A. 1968 Fair Housing Act}

During the early years of the southern civil rights movement, activists focused primarily on the social stigma of racial segregation, instead of the economics of racial subordination. ${ }^{386}$ As the 1960s progressed, however, leaders in the civil rights movement turned their attention to the segregation of housing in the urban North. ${ }^{387}$ Urban riots in Watts (Los Angeles), California and Detroit, Michigan, reflected the anger and frustration of blacks living in ghettoes because of discrimination in the housing market. ${ }^{388}$ Populations in those neighborhoods were concentrated, economic opportunities were few, and the riots made it impossible for lawmakers to ignore the harm caused by that discrimination. $^{389}$ In 1968, members of Congress enacted the Fair Housing Act, which provided a comprehensive approach to fighting race discrimination in real estate transactions. ${ }^{390}$ The members of the 1968 Congress recognized that the concentration of people of color in inner city ghettoes reduced their access to economic opportunities. They sought to stop the subordination caused by the combination of race and economic discrimination in the housing market.

On March 1, 1968, the Kerner Commission issued its report to Congress on race relations in the United States, warning that, "America is dividing into two societies, black and white, separate and unequal." 391 According to the Kerner Commission, one of the chief manifestations of this inequality was residential segregation, which relegated blacks to crowded urban ghettoes. ${ }^{392}$ Testifying on behalf of the Fair Housing Act, Whitney M. Young, Jr., Executive Director of the National Urban League, claimed that crowding in Harlem was so bad that "that if all the U.S. population lived at the same density, it could be housed in three of the five boroughs of New York City." ${ }^{393}$ Members of Congress invoked the unrest in the streets as they spoke in favor of a comprehensive statute that would outlaw race discrimination in real estate transactions and in the real estate industry. ${ }^{394}$ Several representatives explained, all people should have "the right to aspire to a life outside the ghetto, a life in which the tools for

386 See generally BRANCH, supra note 3 (providing a detailed account of the approach of civil rights activists from 1954 to 1963).

387 See Jean Eberhart Dubofsky, Fair Housing: A Legislative History and a Perspective, 8 WASHBURN L.J. 149, 153 (1969).

388 See id. at 154.

389 See id. at 153.

390 See Fair Housing Act, Pub. L. No. 90-284, 82 Stat. 81.

391114 Cong. REC. 4833, 4834 (1968) (statement of Sen. Mondale) (reading from an article in the Washington Post by William Chapman).

392 Id.

393 Civil Rights Act of 1967: Hearing on H.R. 2516 Before the Subcomm. on Constitutional Rights of the Comm. on the Judiciary, 89th Cong. 397, 417 (1967) (statement of Whitney M. Young, Jr., Executive Director, National Urban League).

${ }^{394}$ Dubofsky, supra note 387, at 154. 
individual advancement are equally available to all." 395 The "AntiBlockbusting Provision" of the Fair Housing Act of 1968, which prohibits realtors from using race-based rumors to scare people into selling their homes at a reduced rate, ${ }^{396}$ and a provision of the 1968 Civil Rights Act, which makes it a crime for a person to interfere in certain "federally protected activities," including economic activities, on the basis of their race, were based on Congress's Section 2 power. ${ }^{397}$

Opponents of the Fair Housing Act argued that it violated the Due Process Clause of the Fifth Amendment because it took away the right to convey property without due process of law. ${ }^{398}$ Real estate associations throughout the country opposed the act on that basis. ${ }^{399}$ Opponents also claimed that Congress lacked the power to enact the statute because the Act did not fall within Congress's Fourteenth Amendment power to regulate state action. ${ }^{400}$ They asserted that the statute did not fall within the commerce power because

395 Additional Views of Hon. John Conyers, JR., Hon. Don Edwards, Hon. Jacob H. Gilbert, AND Hon. Robert W. KASTENMEIER, H.R. ReP. No. 89-1678, pt. 2, at 36 (1966).

${ }^{396}$ Fair Housing Act, 42 U.S.C. § 3604(e) (2006).

397 See Civil Rights Act, 18 U.S.C. $\$ 245$ (2006) (providing that the activities protected include including attending a school, participating in a government program, applying for or enjoying employment, serving as a state juror, travel in interstate commerce, or using a public accommodation). A lower court has held that 42 U.S.C. $§ 6705(f)(2)$, a provision of the Local Public Works Capital Development and Investment Act of 1976, requiring ten percent of each grant made to be distributed to minority business enterprises, was a valid exercise of the Thirteenth Amendment enforcement power. See R.I. Chapter, Associated Gen. Contractors of Am. v. Kreps, 450 F. Supp. 338, 346-48, 360-66 (D.R.I. 1978).

398 See, e.g., William M. TuCK, MinORity Views of Hon. William M. Tuck, H.R. ReP. No. 89-1678, pt. 2, at 48 (1966); Civil Rights: Hearings Before the Subcomm. on Constitutional Rights of the Comm. on the Judiciary on S. 3296, Amendment 561 to S. 3296, S. 1497, S. 1654, S. 2845, S. 2846, S. 2923, and S. 3170, 89th Cong., pt. 1, 837-39 (1966) [hereinafter Hearings] (statement of Sen. Strom Thurmond); BASIL L. Whitener, MinORITY Views of the Honorable Basil L. Whitener on H.R. 14765, H.R. ReP. No. 89-1678, pt. 1, at 59 (1966).

399 See, e.g., Hearings, supra note 398, at 525 (statement of J.D. Sawyer, Chairman, Realtor's Ohio Committee, Legislative and Governmental Affairs Committee, Ohio Association of Real Estate Boards, Columbus, Ohio; accompanied by Phil Folk, Legal Counsel and George Moore, President); id. at 864 (statement of John M. Stemmons, Vice Chairman, Legislative Committee, Texas Real Estate Association); id. at 919 (statement of Harry G. Elmstrom, President, New York State Association of Real Estate Boards, Albany, N.Y.); id. at 1064 (statement of Beryl Kenyon, Legislative Counsel, Michigan Real Estate Association).

400 See, e.g., id. at 837 (statement of Sen. Thurmond) ("This title does not even purport to have application to any State involvement or involvement by any official person, or body, of the State"); Basil L. Whitener, Minority Views of the Honorable Basil L. Whitener ON H.R. 14765, H.R. REP. No. 89-1678, pt. 1, at 58 (1966). 
real estate is immobile, and thus not within interstate commerce.401 They ignored the argument that the statute fell within the Section 2 power. ${ }^{402}$

In response, proponents claimed that the statute fell within Congress's power to enforce the Fourteenth Amendment by remedying the states' failure to protect individuals against private discrimination. ${ }^{403}$ This argument echoed the claims of Representative Shellaburger and his Reconstruction allies, ${ }^{404}$ and was articulated by Justice William Brennan in his concurrence in United States v. Guest. ${ }^{405}$ Supporters of the Act believed and hoped that the Court was about to overturn the Civil Rights Cases, in which the Court had imposed the state action requirement of the Fourteenth Amendment. ${ }^{406}$ Supporters also argued that the Act fell within the commerce power because race discrimination in real estate transactions substantially affects interstate commerce. ${ }^{407}$ They noted that the Court had upheld the 1964 Civil Rights Act on that ground in a decision $^{408}$ that was extremely deferential to Congress's power to regulate commerce. $^{409}$ Finally, some supporters of the bill invoked the Section 2 power, pointing out that the Fair Housing Act was similar to the 1866 Civil Rights Act, also based on that power. ${ }^{410}$

Speaking in favor of the Act, members of Congress equated the ghetto with prison. For example, Representative William McCulloch explained that the legislation would be similar to a writ of habeas corpus for a whole race of people because it would "decree that society has no right, no authority to imprison a man in a ghetto, because of his color." 411 Another supporter stated: "Men can be imprisoned outside of jails. The ghetto dweller knows that. The Negro knows that he is caged, that society really gives him nowhere else to

\footnotetext{
401 Hearings, supra note 398, at 837 (statement of Sen. Thurmond)

402 There is no record of any opponent of the 1968 Fair Housing Act mentioning the Thirteenth Amendment.

403 See Hearings, supra note 398, at 88 (statement of Nicholas Katzenbach, Att'y Gen. of the United States).

404 See supra notes 261-63 and accompanying text.

405 United States v. Guest, 383 U.S. 745, 784 (1966) (Brennan, J., concurring in part and dissenting in part).

406 Dubofsky, supra note 387, at 152 (citing the testimony of Attorney General Ramsey Clark, Hearing on S. 1358, S. 2114 and 2280 Before aSubcommittee of the Senate Committee on Banking and Currency, 90th Cong., 1st Sess (1967).)

407 See Hearings, supra note 398, at 85 (statement of Nicholas Katzenbach, Att'y Gen. of the United States).

${ }^{408}$ Heart of Atlanta Motel v. United States, 379 U.S. 241 (1964).

409 See Hearings, supra note 398, at 297 (statement of Sen. Philip A. Hart).

410 See id. pt. 2, at 1148 (statement of Professor Arthur Sutherland of Harvard); id. at 1414 (statement of Edward Rutledge, Executive Director, National Committee Against Discrimination in Housing).

411 Civil Rights Hearings Before the Comm. on H. Res. 1100, 90th Cong. pt. 2, 87 (1968) (statement Rep. McCulloch).
} 
go." ${ }^{12}$ Thus, these members of Congress invoked the Reconstruction Era concern about mobility, and argued that the Act fit within their power to enforce the constitutional provision that prohibits involuntary servitude. As a congressional supporter emphasized:

[T] he 13th amendment to the Constitution forever barred slavery and involuntary servitude in the United States. It was viewed by those who had approved it as abolishing not just enforced service of one person for another but as a guarantee to all citizens, of the outlawing of all the badges and incidents of slavery. One hundred and three years after its adoption the Congress has yet to remove all the disabilities of that servitude. ${ }^{413}$

Like their Reconstruction Era predecessors, supporters of the 1968 Fair Housing Act also argued that they were enforcing the rights of citizenship. One supporter explained: "No matter how far we go away from the basics of the problem, we always get back to the fact that both the poverty areas, white and Negro - principally Negro - in this country have been deprived of the full opportunity to be a full American citizen." ${ }^{14}$ Another claimed that "[a]ny American citizen, since the formation of our country, has had the right to sell or rent his property or make loans to the person of his choice." ${ }^{15}$ Another claimed that the enactment of the Thirteenth, Fourteenth, and Fifteenth Amendments "put our Nation officially on record in support of liberty and equality for all Americans." 416

Congressional debate over the Fair Housing Act was heated. ${ }^{417}$ The measure was introduced in 1966 and lengthy hearings were held that year, ${ }^{418}$ but it did not pass Congress until April of 1968, after the assassination of Martin Luther King set off another wave of riots in urban areas. ${ }^{419}$ Nonetheless, by enacting the 1968 Fair Housing Act, members of the "Second Reconstruction" Congress self-consciously furthered the anti-subordination tradition, establishing that "first class" citizens were entitled to be free of both race-based and economic subordination.

The Supreme Court never ruled on the constitutionality of the 1968 Fair Housing Act, but lower courts uniformly upheld it. In United States v. Bob Lawrence Realty, Inc., the Fifth Circuit held that the Fair Housing Act's "AntiBlockbusting" Provision is a valid exercise of Congress's power to enforce the

412114 Cong. ReC. 9680, 9680 (1968) (statement of Rep. Bell).

413114 CONG. REC. 9553, 9600 (statement of Rep. Corman).

${ }^{414}$ Id. at 9554 (statement of Rep. Madden) (quoting Mayor Ivan Allen, Jr., Atlanta, Ga.).

415 Id. at 9600 (statement of Rep. Dorn).

${ }^{416}$ Id. at 9566 (statement of Rep. Goodell).

${ }^{417}$ For a thorough description of the congressional debate over the Act, see generally Dubofsky, supra note 386.

418 See Hearings, supra note 398.

419 Dubofsky, supra note 386, at 160. 
Thirteenth Amendment. ${ }^{420}$ In United States v. Bledsoe, the Eighth Circuit sustained a conviction under the Hate Crimes provision of the 1968 Act of a defendant who had murdered a man in a public park because he was black. ${ }^{421}$ The court held that the statute fell within the Section 2 power because "interfering with a person's use of a public park because he is black is a badge of slavery." ${ }^{2} 2$ Courts in the Second and Ninth Circuits also upheld the Hate Crimes provision under Section 2.423 It is thus clear that Congress can use its Section 2 power to criminalize private interference with fundamental rights on the basis of race.

\section{B. Anti-Trafficking Victims Protection Act of 2000}

In the 1990s, members of Congress turned their attention to two related issues - violence against women and the international trafficking of women in sex trades - as they renewed the Violence Against Women Act of 1994 ("VAWA") and enacted the Trafficking Victims Protection Act of 2000.424 While the VAWA was based on Congress's power to regulate interstate commerce, $^{425}$ the TVPA was based on Congress's Section 2 power. ${ }^{426}$

${ }^{420}$ United States v. Bob Lawrence Realty, Inc., 474 F.2d 115, 119-21 (5th Cir. 1973) (upholding the statute on the grounds that it "will effectuate the purpose of the Thirteenth Amendment by aiding in the elimination of the "badges and incidents of slavery in the United States"”).

${ }^{421}$ United States v. Bledsoe, 728 F.2d 1094, 1097 (8th Cir. 1984).

${ }^{422}$ Id.

${ }^{423}$ See United States v. Allen, 341 F.3d 870, 873 (9th Cir. 2003) (holding that the statue was a valid exercise of Congressional power under the Commerce Clause or the Thirteenth Amendment); United States v. Nelson, 277 F.3d 164, 213 (2d Cir. 2002) (holding that the Thirteenth Amendment is not restricted to state action). In United States v. Lane, the Tenth Circuit Court of Appeals upheld the conviction of defendants who had killed a Jewish talk show host because of his religion and thus denied him of his "enjoyment of private employment," in violation of the Act. See United States v. Lane, 883 F.2d 1484, 1487, 1492-93 (10th Cir. 1989). In that case, the Court upheld the Act as an exercise of the Commerce Power. Id.

${ }^{424}$ The TVPA and the reauthorization of the Violence Against Women Act were combined in the Conference Report and enacted together. Trafficking Victims Protection Act of 2000, Pub. L. No. 106-386, 114 Stat. 1464, 1464 (codified as amended at 22 U.S.C. $\S \S 7101-7112$ (2006)). Members of Congress remarked that this combination was appropriate given the fact that they were addressed towards interconnected phenomena. See, e.g., 146 CONG. REC. 21,328, 21,343 (2000) (statement of Rep. Maloney). Both bills were top priorities of the bipartisan Women's Caucus. Id.

${ }^{425}$ Violence Against Women Act, Pub. L. 103-322, Title IV, September 13, 1994, 108 Stat. 1902 (codified as 18 U.S.C. $\S \S 2261-2266$ (2006)). In United States v. Morrison, the Court held that the Act fell beyond Congress's power to enforce the Commerce Clause. U.S. v. Morrison, 529 U.S. 598, 617-19 (2000).

426 Trafficking Victims Protection Act of 2000, Pub. L. No. 106-386, § 102(b)(22), 114 Stat. $1464,1468$. 
Supporters of the bill noted that 600,000 to two million women per year are trafficked beyond international borders, with approximately 50,000 entering the United States annually. ${ }^{427}$ They noted that trafficking is "one of the largest manifestations of modern day slavery internationally," 428 and remarked that "[t]he trafficking of human beings for forced prostitution and sweatshop labor is a rapidly growing human rights abuse." 429 In the TVPA, members of Congress recognized that gender and economic subordination are combined in the international trafficking of workers, and adopted a comprehensive approach to end such trafficking.

Supporters of the TVPA explained that the Act was necessary because the problem of sex trafficking had increased rapidly with the growth of the international economy, as had the practice of "debt bondage," wherein "a person can be enslaved to the money lender for an entire lifetime because of a $\$ 50$ debt." 430 They pointed out that this new form of slavery "does not look like the old forms associated with lifetime bondage as a chattel slave." ${ }^{431}$ Like the victims of chattel slavery, some victims of trafficking are kidnapped in their home countries. ${ }^{432}$ Others are "lured into trafficking through false promises of jobs, good working conditions, high pay and foreign adventure." 433 The bill intended to aid all victims of trafficking, regardless of whether these victims were taken by force or their captors used psychological force to detain them. ${ }^{434}$

While the bill was directed primarily at sex trafficking, it was also intended to remedy "slave-like conditions in jobs as domestic workers, factory workers, sex workers, nannies, waitresses, and service workers." ${ }^{35}$ Representative Pryce pointed out that "no matter how they are taken; trafficking victims are universally subject to cruel mental and physical abuse, including beatings, rape, starvation, forced drug use, confinement and seclusion." 436 Representative Pitts contrasted this image with that of the freedom and equality that immigrants expect in the United States. She explained: "As Americans, we have always worked for justice and freedom in our borders and worldwide, and that is what this bill is all about ...."437 Senator Barbara Mikulski

427 See 146 Cong. REC. 22,041, 22,041 (2000) (statement of Sen. Brownback).

428 Id. at 22,044 .

${ }^{429}$ Id. at 22,045 (statement of Sen. Wellstone).

${ }^{430} I d$. at 22,044 (statement of Sen. Brownback).

${ }^{431} \mathrm{Id}$.

432146 Cong. Rec. 21,328, 21,329 (statement of Rep. Pryce).

433146 CONG. REC. H9036, H9044 (daily ed. Oct. 6, 2000) (statement of Rep. MillenderMcDonald).

434 See, e.g., 146 Cong. REC. 22,058, 22,059 (statement of Sen. Wellstone); 146 ConG.

REC. H9038, H9038 (statement of Rep. Hyde).

435146 Cong. Rec. H9044, H9044 (statement of Rep. Millender-McDonald).

436146 Cong. ReC. 21,328, 21,329 (statement of Rep. Pryce).

${ }^{437}$ Id. at 21,342 (statement of Rep. Pitts). 
elaborated: "We want this century to be one of democracy and human rights. We will not achieve this unless everyone, including the worlds' [sic] poorest women, is able to control their own lives." 438

The TVPA contained provisions to give victims of trafficking more control over their lives. Senator Paul Wellstone explained that the traffickers preferred foreign workers because they were more easily intimidated and controlled. ${ }^{439}$ Some captors did little more than steal the passports of the victims, leaving them stranded in a foreign country, and subject to deportation if they complained to the authorities. 440 To remedy this concern, the Act includes provisions making victims of trafficking eligible for public benefits and special visas allowing them to remain in the country at least while their captors are being prosecuted, and enabling them to petition for permanent residency. ${ }^{441} \mathrm{In}$ this way, the Act's sponsors sought to empower victims of trafficking so that they would not be afraid to resist their captors. ${ }^{442}$

Another example of the anti-subordination approach to trafficking in the TVPA is that it applies to not just physical, but also psychological coercion against victims of trafficking. ${ }^{43}$ This provision was an amendment to the Anti-Peonage Act, necessitated by the Supreme Court's ruling in United States v. Kozminski that the Anti-Peonage Act did not apply to psychological coercion. ${ }^{444}$ Representative Hyde explained:

Twelve years ago, the Supreme Court held that our existing anti-slavery statutes only prohibited the use of force or the abuse of the legal process to force a person into involuntary servitude. But the sad fact is that those who traffic in human beings today also use deceptive schemes and other lies, together with threats of force to family members in a home country, to coerce the victim into labor. This bill will now punish that criminal conduct. $^{445}$

${ }^{438} I d$. at 22,054 (statement of Sen. Mikuski).

${ }^{439} I d$. at 22,045 (statement of Sen. Wellstone).

${ }^{440} \mathrm{Id}$.

441 See 22 U.S.C. $\$ 7105$ (2006).

442146 CONG REC. 22,045, 22,046 (statement of Sen. Wellstone).

443 Id. at 22,059.

${ }^{444}$ United States v. Kozminski, 487 U.S. 931, 950 (1988) (holding that the statutes applied only to physical or legal coercion); see also 146 CONG. REC. 22,059, 22,059 (statement of Sen. Wellstone); 146 ConG. REC. 21,337, 21,337 (statement of Rep. Hyde).

445146 Cong. REC. 21,337 (statement of Rep. Hyde). Senator Wellstone cited a similar case in which an "employer" required his farm workers to live in a chicken coop that caught fire, causing the death of a worker. 146 CONG. REC. 22,059 (statement of Sen. Wellstone). Wellstone explained: "Because the labor of the workers was maintained through a scheme of nonviolent and psychological coercion, the case did not fall under the involuntary servitude statutes - which could have result in life sentences given the death of one of the victims. Our legislation changes that. That is why this legislation is so important." $I d$. 
Thus, like the 1948 Amendments to the Anti-Peonage Act, Congress designed the TVPA to overturn cramped Supreme Court interpretations of the meaning of involuntary servitude.

Finally, as with the other Section 2 based legislation, members of the 2000 Congress invoked the Reconstruction Era as they expanded the concept of slavery addressed by the Congress of that era. For example, Senator Brownback declared that the TVPA was not only a significant human rights bill, but also "the largest anti-slavery bill that the United States has adopted since 1865 and the demise of slavery at the end of the Civil War." 446 He saw himself and his colleagues as joining the "[p]eople of conscience [who] have fought against the different manifestation of slavery for centuries." 447 Representative Hyde agreed that "[w]hile Lincoln may have freed the slaves in America, there are those today who engage in other forms of slavery on persons of many colors." 448 Thus, once again, members of Congress invoked Reconstruction as they acted to expand human rights beyond the borders of the United States and more expansively than the Court's understanding of involuntary servitude.

There was virtually no opposition to the TVPA during debates over the Act. The Act had support from both ends of the political spectrum, from Gloria Steinem and the NOW Legal Defense and Education Fund to evangelical groups. ${ }^{449}$ The Act passed both houses of Congress on a virtually unanimous vote. ${ }^{450}$ By enacting the TVPA, members of Congress recognized the link between gender and economic based exploitation that occurs not just within America, but throughout the world. Notably, this civil rights measure - one of the farthest reaching - is based on anti-subordination principles and the Thirteenth Amendment, and is consistent with the goals of the Framers of the Thirteenth Amendment.

The enactment of the TVPA sets up a potential battle between the Court and Congress. The Kozminski decision was arguably based on both statutory and constitutional interpretation. ${ }^{451}$ The Court's reading of $\S 1584$ was merely a

${ }^{446} I d$. at 22,043, 22,044 (statement of Sen. Brownback).

447 Id.

448 Id. at 21,337 (statement of Rep. Hyde).

449 See id. (statement of Rep. Conyers); 146 CONG REC. 22,047 (statement of Sen. Wellstone).

450 The bill passed both houses on a voice vote. 146 CONG. REC. H2687 (daily ed. May 9, 2000); 146 CONG. REC. S7781 (daily ed. July 27, 2000). The conference report was approved in the House by a vote of 371 to 1,146 CONG. REC. 21,346-47 (2000), and the Senate by a vote of 95 to 0.146 CONG. REC. 22,108 (2000).

451 Compare United States v. Kozminski, 487 U.S. 931, 941 (1988) (asserting that since the Kozminskis were convicted of conspiracy to violate "the Thirteenth Amendment guarantee against involuntary servitude[,] . . . our task is to ascertain the precise definition of that crime by looking at the scope of the Thirteenth Amendment prohibition of involuntary servitude"), with id. at 944 ("We draw no conclusions from this historical survey about the potential scope of the Thirteenth Amendment."). 
matter of statutory interpretation because the Court limited itself to determining what Congress had understood "involuntary servitude" to mean when they amended the Anti-Peonage Act in 1948.452 However, the Court's understanding of the term "involuntary" was based on how it had defined the meaning of the term "involuntary servitude" for the Thirteenth Amendment. ${ }^{453}$ To the extent that Kozminski is a constitutional decision, the Court, influenced by Boerne, might find the TVPA to be unconstitutionally inconsistent with its own interpretation of the Thirteenth Amendment, notwithstanding the deferential precedent of Jones. ${ }^{454}$ However, Justice O'Connor, writing for the Court, framed the decision as a matter of mere statutory interpretation. ${ }^{455}$ She emphasized the fact that the Court relied on a doctrine of narrow construction of criminal statutes, not a reading of the Constitution. ${ }^{456}$

Despite this potential conflict, lower courts have consistently upheld the TVPA. For example, in United States v. Marcus, Judge Ross of the Eastern District of New York upheld a conviction under the TVPA of a defendant who had used a psychologically and physically coercive sexual relationship to obtain the victim's sexual labor or services. ${ }^{457}$ The judge rejected defendant's citation of Kozminski and instead relied on the TVPA, observing that "the TVPA's legislative history makes clear that Congress enacted $\S 1589$ as a response to the Court's decision in Kozminski." 458 Similarly in United States $v$. Bradley, a case involving charges of coerced labor, the First Circuit found that a jury instruction that defendants could be convicted even if the workers were physically able to flee was proper under the TVPA. ${ }^{459}$ The judge also treated the TVPA as overruling the Court's interpretation of the Anti-Peonage Act in

${ }^{452} I d$. at 948 .

${ }^{453}$ Id. at 941 .

${ }^{454}$ See City of Boerne v. Flores, 521 U.S. 507, 520 (1997) (establishing “congruence and proportionality" test restricting Congress's authority to enact civil rights legislation pursuant to the Commerce Clause and the Fourteenth Amendment); Jones v. Alfred H. Mayer, Co., 392 U.S. 409, 439 (1968) (holding that the authority of Congress to enforce the Thirteenth Amendment by "appropriate legislation" includes the power to eliminate all racial barriers to the acquisition of real and personal property). However, significant differences between the Thirteenth and Fourteenth Amendments justify more judicial deference toward Congress's power to enforce the former. William M. Carter, Jr., Judicial Review of Thirteenth Amendment Legislation: "Congruence and Proportionality" or "Necessary and Proper”?, 38 U. TOL. L. REV. 973, 982 (2007).

455 See Kozminski, 487 U.S. at 944.

456 See id.

457 United States v. Marcus, 487 F. Supp. 2d 289, 304, 313 (E.D.N.Y. 2007), vacated, 538 F.3d 97 (2008) (vacating and remanding on ex post facto grounds), cert. granted, $130 \mathrm{~S}$. Ct. 393 (2009) (No. 08-1341).

${ }^{458} I d$. at 302.

${ }^{459}$ United States v. Bradley, 390 F.3d 145, 152-54 (1st Cir. 2004), sentence vacated, 545 U.S. 1101 (2005). 
Kozminski. 460 Thus, the lower courts agree that Congress had the power to enact the TVPA, and are willing to enforce it as a potent tool of antisubordination.

\section{CONCLUSION: FREed AT LAST! The Future OF SECTION 2}

Both the language and the history of the Thirteenth Amendment make that provision a promising source of rights of belonging. Section 2 empowers Congress to address race discrimination from the standpoint of an antisubordination theory of equality, taking into account the economic circumstances that have contributed to the subordination of people of color throughout the history of our country. ${ }^{461}$ Section 2 also enables Congress to take a comprehensive look at the conditions of workers in our country and enact legislation to remedy exploitative conditions in the workplace. ${ }^{462}$ Finally, Section 2 enables Congress to remedy sex discrimination and gender based violence. ${ }^{463}$ As long as members of Congress reasonably believe that the practice they are addressing amounts to slavery or involuntary servitude, or the badges or incidents of slavery, Section 2 gives them the authority to act. Section 2 thus gives members of Congress the power to redefine the meaning of "equality" in our society and to address the interconnection of gender, race, and economic subordination.

Most clearly, Congress may rely on Section 2 to address the problematic relationship between race discrimination and economic distress in our society. The members of the Reconstruction Congress understood that slaveholders relied upon racism as a social mechanism to legitimate slavery, the exploitation of the labor of people of color. Thus, members of Congress could use Section 2 to outlaw practices that have a discriminatory impact on racial minorities, regardless of evidence of discriminatory intent. ${ }^{464}$ Section 2 also empowers

$460 I d$. at $150-51$.

461 See supra Parts II-III.

462 See supra Part IV.

463 See supra Part V.B.

464 See Carter, supra note 27, at 1328-29 (suggesting that the Thirteenth Amendment could be used to defend against religiously motivated hate crimes and racial profiling of Arabs and Muslims); Miller, supra note 27, at 1045 (arguing that Congress might use its Thirteenth Amendment power to prohibit disparate impact discrimination, and to prevent individual isolated discrimination if it determines that the discrimination would "have the effect of locking out African Americans from valuable social, economic, or political opportunities"). Unlike its interpretation of the Fourteenth Amendment, the Supreme Court has not limited the Thirteenth Amendment to intentional discrimination. See Gen. Bldg. Contractors Ass'n Inc. v. Pennsylvania, 458 U.S. 375, 389, 390 n.17 (1982) (holding that 42 U.S.C. $§ 1981$ only applies to intentional discrimination, but noting it need not decide whether "the Thirteenth Amendment itself reaches practices with a disproportionate effect as well as those motivated by a discriminatory purpose, or indeed whether it accomplished anything more than the abolition of slavery"); Memphis v. Greene, 451 U.S. 100, 128-29 
Congress to consider the meaning of liberty within the employment relationship and outlaw practices that members of Congress reasonably believe deprive workers of their liberty. ${ }^{465}$ Finally, Section 2 may empower Congress to address gender discrimination and economic injustice within the realm of family law. 466

The abolitionist roots of the Thirteenth Amendment are still relevant in twenty-first century society. Section 2 empowers Congress to protect fundamental human rights and enables outsiders to belong as fully productive members of our society, free from race discrimination and economic exploitation. When members of Congress have acted to enforce the Thirteenth Amendment, they have tried to eliminate the roots of inequality in our society with a comprehensive anti-subordination approach. In the twenty-first century, members of Congress should continue to address both private and government practices that impede the ability of the historically disempowered to participate effectively in our society, and thereby redefine the meaning of "equality."

(1981) (declining to "speculate about the sort of impact on a racial group that might be prohibited by the Thirteenth Amendment" since the impact in that case did not violate it).

465 For example, Congress might want to legislate to improve the rights for immigrant workers who are required to work in sweatshop-like conditions. See Kim, supra note 228, at 942; Ontiveros, supra note 27, at 925 (arguing that the Thirteenth Amendment "sought to protect workers by providing a floor for free labor, under which no worker may struggle"). Members of Congress could also rely on Section 2 to amend the National Labor Relations Act to reinvigorate the right to strike by prohibiting the employer's hiring of replacement workers. On the loss of the right to strike, see Pope, supra note 356, at 527-34.

466 Throughout the debates over the Thirteenth Amendment, members of Congress deplored the impact that slavery had on families. Many pointed out that slaves had been unable to maintain families, that slavery had led to the loss of their loved ones, and that the end of slavery should provide an opportunity for freed slaves to begin a family life. For example, Ebon Ingersoll argued that one of the "God given rights" of freed slaves was the "right to endearments and the enjoyment of family ties." See Cong. Globe 38th Cong., 1st Sess., 2989, 2990 (1864). 